\title{
Impact of building material recycle or reuse on selected emergy ratios
}

\author{
N.Y. Amponsah, B. Lacarriere, N. Jamali-Zghal, O. Le Corre ${ }^{1}$ \\ GEPEA, Ecoles des Mines de Nantes, CNRS, UMR 6144, GEM, PRES UNAM, 4, rue Alfred \\ Kastler, B.P. 20722, F-44307, Nantes, Cedex 3, France
}

\section{Abstract}

While the emergy evaluation method has been used successfully in recycling processes, this area of application still requires further development. One of such is developing emergy ratios or indices that reflect changes depending on the number of times a material is recycled. Some of these materials may either have been recycled or reused continuously as inputs to a building, for example, and thus could have various impacts on the emergy evaluation of the building. The paper focuses on reuse building materials in the context of environmental protection and sustainable development. It presents the results of an emergy evaluation of a low-energy building (LEB) in which a percentage of input materials are from recycled sources. The corresponding impacts on the emergy yield ratio $\left(E Y R_{B}\right)$ and the environmental loading ratio $\left(E L R_{B}\right)$ are studied. The EYR which is the total emergy used up per unit of emergy invested, is a measure of how much an investment enables a process to exploit local resources in order to further contribute to the economy. The ELR however, is the total nonrenewable and imported emergy used up per unit of local renewable resource and indicates the stress a process exhibits on the environment. The evaluation provides values for the selected ratios based on different recycle times. Results show that values of the emergy indices vary, even more, when greater amounts of material is recycled with higher amount of additional emergy required for recycling. This provides relevant information prioritizing the selection of materials for recycling or reuse in a building, and the optimum number of reuse or recycle times of a specific material.

Keywords: Emergy, Recycle, Low-energy building

Corresponding author

E-mail address: Olivier.Le-Corre@mines-nantes.fr (O. Le Corre) 


\section{Introduction}

Almost $40 \%$ of the world's consumption of materials converts to the built environment, and about $30 \%$ of energy use is due to housing (Pulselli et al., 2007). The building sector is the biggest consumption sector, before transports sector. As a result, there are ongoing research works to investigate how to significantly reduce the consumption of energy and material flows in the building industry. In effect, terms such as low-energy and passive house are used more frequently all over Europe.

Reuse and recycling of building material is a growing area of interest and concern in many parts of the world. Current practices and trends in the building material waste management are examined from a building life cycle standpoint or cradle to grave concept. To evaluate buildings and their environmental impacts more effectively, several tools and methods are adopted. These methods provide a list of indicators, based on objective values that compare buildings' performances and impacts to their environmental constraints. Some examples of these are the life cycle analysis (Guinée et al., 2001), the emergy analysis (Odum, 1996), the ecological footprint (Rees \& Wackernagel, 2004), and the exergy analysis (Szargut et al., 1988). All of these assessments are needed to develop a comprehensive waste management plan for specific projects.

The use of construction waste management techniques which rely on recycle and reuse of materials have proven to have economic benefits for the construction industry (Kralj, 2007). Reuse is a means to prevent solid waste from entering the landfill, and increase the material, educational and occupational wellbeing of citizens by taking useful products discarded by those who no longer want them and providing them as inputs to the construction of buildings. In many cases, reuse reduces raw material inputs to a very large extent. This is important since a significant percentage of the total natural resources that are used in industrialized countries are exploited by the building industry (Peuportier et al., 1996). High quantities of raw material inputs for building construction results in high energy required for the extraction and processing of these materials. 
Emergy evaluation has been widely applied in the evaluation of ecological systems, energy systems, and environmental impacts of processes, generating a large number of studies. Yet, despite such a wide debate, only a few studies have been produced concerning applications of emergy evaluation to building construction and to building materials. In most of these studies, emergy evaluation is employed as an environmental indicator for construction activities, building materials production and recycling (Buranakarn, 1998; Odum, 2002; Brown \& Buranakarn, 2003; Huang \& Hsu, 2003; Meillaud et al., 2005; Pulselli et al., 2007). Odum (2002) presents a broad approach to the relationships of building construction with materials circulation and energy hierarchy.

In the emergy approach, buildings are a storage of materials that is the sum of the inputs during the construction process. This storage loses emergy as building materials depreciate along time and become dispersed in the environment. New inputs by means of maintenance and repair actions keep the emergy flow into the building system.

Buranakarn (1998) and Brown \& Burnakarn (2003) proposed a set of emergy indices to evaluate recycling patterns and recyclability of building materials. These emergy indices are suggested to measure the environmental benefits of three recycling trajectories: material recycle, by-product use, and adaptive reuse, i.e. recycling the material for a different purpose. The reuse option in the sense of reusing a product elsewhere was not considered in these studies. Emergy per mass is also pointed as a good indicator for recyclability. Buranakarn (1998) and Brown \& Burnakarn (2003) also recognize that materials with higher emergy per mass are more suitable for being recycled by human systems due to their 'quality', and have more environmental impacts when released to the environment. In the context of an environmental approach, Huang \& Hsu (2003) proposed a set of indicators based on emergy to measure the effects of construction in Taipei's sustainability:

(a) intensity of resource consumption;

(b) inflow/outflow ratio;

(c) urban livability; (d) efficiency of urban metabolism; and (e) emergy evaluation of urban metabolism. The relevance of emergy analysis for that study was in the fact that it enabled the consideration of biophysical value of resources to the economic system. 
1 both an understanding of their relative value and contribution to the ecological-economic 2 system (urban construction is equivalent to $44 \%$ of the Emergy used in Taipei), and a 3 measure of the ecological interface of rapid urban development (environmental load of 4 construction waste generation and recycling opportunities).

Meillaud et al. (2005) applied emergy analysis to evaluate an experimental building of three stories containing faculty and students' offices and a workshop, built in 1981, by including environmental, economical, and information flows. By including information flows generated by building occupants to the analysis of the whole building system, it was possible to calculate the outputs generated by the building usage: emergy per educated student, emergy per publication, emergy per course and emergy per 'service'. The significance of emergy per unit was highlighted by Meillaud et al. (2005), since there were few available emergy per unit references for most commodities as inputs to a building.

Another application of emergy to building construction was published by Pulselli et al. (2007). The authors proposed a set of environmental indices to provide a basic approach to environmental impacts of buildings by accounting for the main energy and materials inflows within the building construction process, maintenance, and use:

(i) Building emergy per volume (Em-building volume): this represents the and comparing different building typologies, technologies and materials, regarding different manufacturing processes, maintenance, use, thermal efficiency and energy consumption. Pulselli et al. (2007) argue that buildings are like full emergy reservoirs

27 (storage) that persists in time, and that emergy evaluation of a building highlights the 
1 the most extensive Emergy study was developed by Buranakarn (1998) in order to identify

2 recycling patterns. The author analyses several common materials.

3

4

The main aim of this paper is to extend the emergy based methodology to continuous matter reuse as devised by Amponsah et al. (2011) to a process. In fact, authors consider that the additional emergy (coming from each recycle matter) can be aggregated to the "classical" emergy evaluation which does not include any recycling. The different impacts this continuous reuse might have on the emergy yield ratio (EYR) and the environmental loading ratio (ELR) on the whole process require new definitions.

The rest of this paper is organized as follows: in section 2, relevant literature on emergy evaluation and its application in buildings are reviewed. The methodology developed by Amponsah et al. (2011) is outlined and defined in its specific context. In Section 3, a case study is presented on a low energy building that corresponds to the present construction standards in France. Section 4 presents a discussion and finally, section 5 concludes the paper.

\section{Materials and methods}

With reference to the work and formulae developed by Buranakarn (1998) and Amponsah et al. (2011) respectively, the output emergy of a system involving recycle inputs differs marginally from a similar system with $100 \%$ raw material inputs. Amponsah et al. (2011) further explained that the continuous recycling of a specific material due to the additional emergy required at each stage of recycle, impacts on the final output emergy of the system usually increasing the output emergy after each additional recycle.

As such, authors of the said paper pointed out that the specific emergy of any material $e_{m}$, containing a recycled part (or reused part) $q_{m}$, has a dynamic equation at discrete time, see equation (1), according to the specific total emergy inputs $e_{m i}$ (emergy of raw material, fuel, goods and services etc.) without recycle, and the specific additional emergy needed for recycling (for reusing) $e_{m c}$. The sampling time for recycling is noted Te 
1 and the recycling number is noted $n_{m}$. As such the discrete time $t$ is just equal to the

2 product Te by $n_{m}$. For unitary amount of matter, one gets:

$e_{m}(t)=e_{m i}(t)\left(1-q_{m}(t)\right)+q_{m}(t) e_{m c}(t)+q_{m}(t) e_{m}(t-1)$

The specific emergy of any matter at the $n^{\text {th }}$ recycling is the sum of three terms: the specific emergy of raw material adjusted to its raw mass, the specific additional emergy adjusted to its recycled part and the part coming from the past within the matter itself adjusted to its recycled part. Amponsah et al. (2011) detailed that there is no doublecounting in this decomposition and the pathway of the recycled matter is followed.

Equation (1) is in a general form. Assuming that the specific emergy inputs $e_{m i}$ and the specific additional emergy needed for recycling $e_{m c}$ and the recycled part $q_{m}$ are independent of the discrete time, the specific emergy of matter containing a recycled part can be easily calculated by underlying the sum of a geometric series, noted $\psi$ :

$e_{m}(1)=e_{m i}+e_{m c} q_{m}$ for the $1^{\text {st }}$ Recycle, where the factor $\psi=q_{m}$

$e_{m}(2)=e_{m i}+e_{m c}\left(q_{m}+q_{m}^{2}\right)$ for the $2^{\text {nd }}$ Recycle, where $\psi=q_{m}+q_{m}^{2}$

$e_{m}(3)=e_{m i}+e_{m c}\left(q_{m}+q_{m}^{2}+q_{m}^{3}\right)$ for the $3^{\text {rd }}$ Recycle, $\psi=q_{m}+q_{m}{ }^{2}+q_{m}{ }^{3}$

$e_{m}(4)=e_{m i}+e_{m c}\left(q_{m}+q_{m}^{2}+q_{m}^{3}+q_{m}^{4}\right)$ for the $4^{\text {th }}, \psi=q_{m}+q_{m}{ }^{2}+q_{m}{ }^{3}+q_{m}{ }^{4}$ and so on.

Emergy evaluation classifies inputs into three categories: purchased, renewable, and non renewable. On the basis of these classes, some indicators can be computed in order to assess the sustainability of the use of resources (Lagerberg;1999):

- the emergy yield ratio (EYR) is the emergy of an output divided by the emergy of those inputs to the process that are purchased from the economy;

- the emergy investment ratio (EIR) is the purchased emergy from the economy (services and other resources) divided by the free emergy inflow from the environment.

- the environmental loading ratio (ELR) is the ratio of purchased and nonrenewable indigenous emergy to free environmental emergy. 
On this basis, Amponsah et al. (2011) extended these ratios to some dimensionless emergy indices for a single recycled material. Assuming that the emergy inputs $e_{m i}$ and $e_{m c}$ and the recycled part $q_{m}$ are constant, these ratios are in connection with the pathway of

4 the recycled material by the number of recycle times. Thus, by means of the geometric 5 series:

$7 \quad \operatorname{EYR}_{m}\left(q_{m}, n_{m}\right)=\frac{\left(e_{m i}+\psi e_{m c}\right)}{\left(e_{m i F}+\psi e_{m c F}\right)}$

$$
\operatorname{EIR}_{m}\left(q_{m}, n_{m}\right)=\frac{\left(e_{m i F}+\psi e_{m c F}\right)}{\left(e_{m i N}+\psi e_{m c N}\right)+\left(e_{m i R}+\psi e_{m c R}\right)}
$$

$$
E L R_{m}\left(q_{m}, n_{m}\right)=\frac{\left(e_{m i F}+\psi e_{m c F}\right)+\left(e_{m i N}+\psi e_{m c N}\right)}{\left(e_{m i R}+\psi e_{m c R}\right)}
$$

Where $e_{m i}$ is the specific emergy of raw material use without recycle, and $e_{m c}$ is the 11 additional emergy needed for recycling. Their renewable part is indexed by $R$, the non renewable part by $N$ and the purchased part by $F$, so $e_{m i}=e_{m i F}+e_{m i R}+e_{m i N}$, see figure 1 .

If only one single matter with its associated pathway is considered, the total emergy for processing is increased by its additional emergy $\Delta E_{m c}\left(q_{m}, n_{m}\right)$ :

$$
\Delta E_{m c}\left(q_{m}, n_{m}\right)=m_{m} e_{m c} q_{m}\left(\frac{q_{m}^{n_{m}}-1}{q_{m}-1}\right)
$$

where $m_{m}$ is the mass of the considered material, $q_{m}$ is its mass fraction of recycle, $n_{m}$ is its number of recycle, $e_{m c}$ is the specific emergy required for $100 \%$ recycle.

For $M$ recycled materials in a process indexed by $P$, such as building manufacturing, dimensionless ratios for the entire process can be defined as: 
1

2

$$
E Y R_{P}=\frac{E_{P}^{0}+\sum_{j=1}^{M} \Delta E_{j c}\left(q_{j}, n_{j}\right)}{E_{P F}^{0}+\sum_{j=1}^{M} \Delta E_{j c F}\left(q_{j}, n_{j}\right)}
$$$$
E I R_{P}=\frac{E_{P F}^{0}+\sum_{j=1}^{M} \Delta E_{j c F}\left(q_{j}, n_{j}\right)}{E_{P N}^{0}+E_{P R}^{0}+\sum_{j=1}^{M}\left(\Delta E_{j c N}\left(q_{j}, n_{j}\right)+\Delta E_{j c R}\left(q_{j}, n_{j}\right)\right)}
$$

$$
E L R_{P}=\frac{E_{P F}^{0}+E_{P N}^{0}+\sum_{j=1}^{M}\left(\Delta E_{j c F}\left(q_{j}, n_{j}\right)+\Delta E_{j c N}\left(q_{j}, n_{j}\right)\right)}{E_{P R}^{0}+\sum_{j=1}^{M} \Delta E_{j c R}\left(q_{j}, n_{j}\right)}
$$

Where $E_{P}^{0}$ is the total emergy of the process without any recycle matter. $E_{P F}^{0}, E_{P R}^{0}$ and $E_{P N}^{0}$ are respectively its purchased, renewable and non renewable part. The additional emergy of the $j^{\text {th }}$ matter $\Delta E_{j c}$ is also decomposed into its three parts (purchased, renewable, and non renewable).

Buranakarn (1998) obtained the value for the main materials likely to be recycled in building construction:

- bricks: $e_{b i}(100 \%)=3.68 E+09 \mathrm{seJ} / \mathrm{g}$, when reused $e_{b c}(100 \%)=2.6 E+05 \mathrm{seJ} / \mathrm{g}$ and when recycled $e_{b c}(100 \%)=4.8 E+05 \mathrm{seJ} / \mathrm{g}$, see Amponsah $(2011, \mathrm{p} 158-160)$

- steel via the electric arc furnace process: $e_{s i}(100 \%)=4.15 E+09 \mathrm{seJ} / \mathrm{g}$, $e_{s c}(100 \%)=9.0 E+07 \mathrm{seJ} / \mathrm{g}$, see Buranakarn $(1998, \mathrm{p} 52)$

- aluminium: $\quad e_{a i}(100 \%)=1.27 E+10 \quad \mathrm{seJ} / \mathrm{g}, \quad e_{a c}(100 \%)=6.4 E+08 \quad \mathrm{seJ} / \mathrm{g}, \quad$ see Buranakarn (1998, p60)

- plastic lumber: $e_{p i}(100 \%)=5.75 E+09 \mathrm{seJ} / \mathrm{g}, \quad e_{p c}(100 \%)=5.8 E+08 \mathrm{seJ} / \mathrm{g}$, see Buranakarn (1998, p76)

\section{Case Study}

Low energy buildings involve the reduction of fossil fuel use such as oil, gas and coal, which enhances sustainable building and development. There are many ways to make a building energy-efficient: by high insulation, using building components resulting in less thermal bridges, buildings with good air tightness or by technical installations such as mechanical heat recovery ventilation, which also benefits the indoor climate (Andersson et al, 2006; Wargocki and Wyon, 2007). 
The building studied is located in Theys (Isère) which is a small town $30 \mathrm{~km}$ far from

2 Grenoble. It is defined by a net area of $155 \mathrm{~m}^{2}$ calculated as the sum of the living area 3 plus the garage area. It is intended for residential use. It comprises a basement, a ground

4 floor and one other floor. The structure consists of a reinforced concrete frame with pillars and beams. The walls are made of concrete blocks with an internal insulation layer and gypsum plastering. The external wrapping is formed by two side walls (adjoining blocks), two facades (brickwork with cavities), an insulated basement. The upper ceiling is covered with mineral wool, under clay tiles roof. The house is heated by a natural gas boiler. The aluminum glass windows are double glazed with an overall heat transfer coefficient of $1.1 \mathrm{~W} / \mathrm{m}^{2} \mathrm{~K}$. The annual heating consumption is of $50 \mathrm{kWh} / \mathrm{m}^{2}$, corresponding to the upper limit for the French label low-energy building.

An inventory of inputs to the construction process with relative raw data has been drawn and the quantity of materials and their compositions are reported in a succession of steps that cover from the first to the last brick settled. Raw data (mass quantities) in the building metric computation has been reported in Table 1, and has been processed through the relative transformities and expressed in terms of solar emergy joules. References for transformities used in the table are from: Odum et al. (2000); Brown and Buranakarn (2003); Meillaud et al. (2005); Odum (1996).

Emergy flows have been reported relative to the materials used to build each component and structural part. In this case, human labor is not considered. The composition and the percentage of the main building materials used, assists in knowing the main material inputs for the construction of the building. The subsequent emergy results enable us to make a list of building materials based on their 'environmental cost' (in terms of seJ) that depends on both their quantity and their transformity (quality). 
- Line 1 , the sun primarily serves as a source of light for site workers during the daytime of work. The sun also helps in drying material used in construction (such as, concrete, mortar, paints, etc...), see Pulselli et al. (2007) and Meillaud et al. (2005).

- The electricity breakdown used, come from the energy mix in France, see website U.E. 2007. Since electric energy is purchased to national grid, authors chose to make no distinction from the source.

- The renewable emergy part of whole building construction is considered as the sum of sun and water emergy. Its purchased emergy part is considered as the sum of fuel and electricity emergy.

- In Table 1 , the value of transformities corresponds to a process with no recycling. Without any recycled material, the total emergy for building manufacturing, noted $E_{B}^{0}$, is $7.11 \mathrm{E}+16 \mathrm{seJ}$, sharing in its renewable inputs (line $\left.1 \& 2\right) E_{B R}^{0}$, in its non renewable inputs (line 3-65) $E_{B N}^{0}$ and in its purchased inputs (line 66-70) $E_{B F}^{0}$. The index $\mathrm{B}$ refers to building construction, the process studied in the case study, and the exponent 0 refers to any recycled material.

- It is observed that concrete takes about $74 \%$ in mass of the entire material inputs of the building followed by bricks.

Emergy values of the main individual materials are also presented in Fig. 2. It can again be observed that concrete still remains a significant material not only in quantity use but also in terms of its emergy input to the building. This is because although concrete does not have a too high transformity value, it is used in a very large proportion in the construction and thus it becomes responsible for a large share of the total emergy (65\%) of the total material input.

Figure 2. Emergy inputs of main raw materials in constructing the building 
Fig. 2 shows, however, that limestone (which has the third largest input quantitatively) falls out when emergies are considered. This is explained by the low

3 transformity value $(1.68 \mathrm{E}+09 \mathrm{seJ} / \mathrm{kg})$ of limestone. Inversely, PVC, though slightly low in

4 consumption, have a high value of transformity $(9.86 \mathrm{E}+12 \mathrm{seJ} / \mathrm{kg})$. This makes PVC a good choice for recycling or reuse, since it has a high embodied energy per unit mass. Nevertheless, PVC cannot have a significant effect on the emergy of the building construction.

\section{Discussion}

First, authors consider only one matter, the bricks, since they were found to be the second most used material in the construction of the building (after concrete), accounting for about $19 \%$ of the total material input. Though it might not be the best example of a reusable or recyclable material in building, compared to PVC, steel etc, the idea is to illustrate the developed procedure of emergy evaluation. The emergy of the building is thus re-evaluated, taking into account different scenarios. As such, emergy for sorting, collection and transportation to the recycling plant is considered, in addition to the emergy for the plant process. This emergy adds up to give the additional emergy of bricks recycling $\left(\Delta E_{\mathrm{bc}}\right)$. For this building, the specific emergy of bricks (with a total mass of 3767 $\mathrm{kg}$ ) is $e_{b c}=2.6 E+05 \mathrm{seJ} / \mathrm{g}$ if $100 \%$ reused and $e_{b c}=4.8 E+05 \mathrm{seJ} / \mathrm{g}$ if $100 \%$ recycled. Numerical application gives an emergy of $9.9 \mathrm{E}+11$ seJ when reused and $1.81 \mathrm{E}+12$ seJ when recycled. This is then multiplied by the quantity $\left(q_{\mathrm{b}}=30 \%\right.$ in this case) of recycled

21 (or reused) bricks. Authors assume that this additional emergy $\Delta E_{b c}\left(q_{m}, n_{m}\right)$, corresponds mainly to collection and separation, and is incorporated only in purchased inputs $\Delta E_{b c F}\left(q_{m}, n_{m}\right)$. Equation (10) begins:

$$
E Y R_{B}=\frac{E_{B}^{0}+\Delta E_{b c F}\left(q_{b}, n_{b}\right)}{E_{B F}^{0}+\Delta E_{b c F}\left(q_{b}, n_{b}\right)}
$$

- The result for the first reuse $\left(q_{\mathrm{b}} e_{\mathrm{bc}}\right)$ is added up to the initial emergy of the building (ref. Table 1) 7.1E+16 seJ giving an emergy difference of $5.4 \mathrm{E}+11$ seJ. Results for recycled bricks are proposed in Table 2, in the case of $30 \%$ recycle rate of bricks $\left(q_{b}\right)$ and for different number of times of recycling. 
- For the first reused bricks, the numerical application gives the emergy difference of $2.99 \mathrm{E}+11$ seJ. Results for reused bricks are proposed in Table 3 always in the case of $30 \%$ reuse part and for different number of times of reuse.

\section{This is continued for different number of times of recycle and for different quantities to} assess the various impacts on the emergy analysis of the building (refer to equations 2 to $5)$.

Table 2. Emergy results for bricks recycling for different recycling times.

Table 3. Difference in emergy involving a part of material recycle and initial emergy of building for reuse of bricks (e.g. in concrete mix)

The same scenario is used to analyze the various effects on the emergy yield ratio. It is seen from the results presented that the EYR decreases with respectively an increase of recycling time in Fig. $3 a$ and reusing time in Fig 3b. This is explained by the increase of additional goods and services purchased to aid in the recycling process. Figs. $4 \mathrm{a}$ and $4 \mathrm{~b}$ show respectively the potential impact of recycled bricks (Figure $4 a$ ) and reused bricks (Figure $4 \mathrm{~b}$ ) on the emergy yield ratio $\left(E Y R_{B}\right)$ of the building. Without any recycling $E Y R_{B}$ is the ratio of the total emergy for building construction ( $7.11 \mathrm{E}+16 \mathrm{se})$ to the emergy part purchased from economy $(1.98 \mathrm{E}+13 \mathrm{se})$. Numerical application gives $3.59 \mathrm{E}+3$. This value means that the purchased emergy part is low. As presented in table (2) for recycling or table (3) for reusing, the additional emergy $\Delta E_{b c}\left(q_{m}, n_{m}\right)$ is about $1 \%$ of $E_{B F}^{0}$ so the bricks recycling, or the bricks reusing, has a low impact on the ratio $E Y R_{B}$ for the building construction, see Figs $3 \mathrm{a}$ and $3 \mathrm{~b}$. Since bricks reusing emergy is approximately half the one for recycling, the impact of reusing on $E Y R_{B}$ is lower than the one for recycling. The greater the number of recycling (or reusing) is, the lower the $E Y R_{B}$ is and consequently the proportional part of purchased economy increases, see Figs 4a and 4b. 
Common sense has it that both recycling and reusing tend toward sustainability.

Hence, Ulgiati et al. (2004) proposed a path of emergy allocation in which the emergy rules not violated. In this, the emergy invested in the treatment and recycling process should be assigned to the recycled resource. As such, the proposal suggests that wastes only bear the additional emergy inputs needed for their further processing. Ulgiati et al. (2004) then amounted to 'reseting' the emergy content in recycling processes to eliminate the problem of cumulative emergy.

Figure 3. Impact of $30 \%$ (constant rate) continuous bricks recycle (a) and reuse (b) on $\mathrm{EYR}_{\mathrm{B}}$ of the building

Figure 4. Impact of different recycling rates for continuous bricks recycle (a) and reuse (b) on $\mathrm{EYR}_{\mathrm{B}}$ of the building

Authors consider one additional material, the plastic, its mass is $171 \mathrm{~kg}$ and its specific recycle emergy is $5.8 \mathrm{E}+08 \mathrm{seJ} / \mathrm{g}$. For $30 \%$ of recycled part, the value of the first recycling (2.98 E+13 se] corresponding to the product of specific transformity $5.8 \mathrm{E}+13 \mathrm{seJ} / \mathrm{kg}$ by its mass $171 \mathrm{~kg}$ and by its recycle part $30 \%$ ) is greater than the purchased emergy for the building construction (1.98 E+13 se J). So the impact of plastic recycling is very significant on $E Y R_{B}$, see Fig. 5. Fig.6 shows the impact of recycled plastic on the emergy yield ratio $\left(E Y R_{B}\right)$ of the building.

Figure 5. Impact of $30 \%$ (constant rate) continuous plastic recycle on $\mathrm{EYR}_{\mathrm{B}}$ of the building Figure 6. Impact of different recycling rates for continuous plastic recycle on $\mathrm{EYR}_{B}$ of the building

As can be seen in the results of the $\mathrm{EYR}_{\mathrm{B}}$, ignoring the impact of material reuse or recycling leads to the loss of significant information. Extending the traditional $E Y R_{B}$ to include the recyclable values from the additional emergy needed for recycling, increases the value associated to the purchased goods and services and thus reduces the EYR $\mathrm{B}_{\mathrm{B}}$. It is 
1 observed that $\mathrm{EYR}_{B} \mathrm{~S}$ are lower in higher recycling times. For instance, the difference 2 between $\mathrm{EYR}_{\mathrm{B}}$ for a $1^{\text {st }}$ recycle and a $5^{\text {th }}$ recycle is quite significant $(3.92 \mathrm{E}+01)$. This is due 3 to the significant changes in the additional emergy amounts needed for the cycle of 4 material recycling or reuse.

5

In the case only one material is recycled (or reused), bricks for example, the emergy loading ratio for building construction $E L R_{B}$ is defined as:

$$
E L R_{B}=\frac{E_{B F}^{0}+E_{B N}^{0}+\Delta E_{b c F}\left(q_{b}, n_{b}\right)}{E_{B R}^{0}}
$$

$E L R_{B}$ is increasing with both the recycle part (or reuse part), and the number of cycles. A higher $\operatorname{ELR}_{B}$ suggests that investing in waste management causes more environmental stress. This is due to the fact that the purchased inputs from the economy needed for recycling, or resuing, increase.

Figure 7. Impact of different recycle rates (a) and reuse rates (b) for continuous bricks recycle on $\mathrm{ELR}_{\mathrm{B}}$ of the building

Fig.7a and 7b show that the developed methods if utilized would serve as an extension to quantify and interpret the attributes of systems with percentages of respectively recycled inputs and reused inputs, with important implications in comparative decision making.

Before conclusion, authors would like to emphasize on two major points

- Equations (10-12) have been introduced to study the impact of several recycled materials (or reused) with different parts and at different numbers of recycling (or reusing) on emergy assessment of a process. In this paper, it does not worth it to multiply numerical applications. It is possible to mix the assessment of bricks and plastic recycling, and so on.... This paper provides the method.

- It is very important to know the industrial process for recycling (or reusing), in other words the pathway of the recycled (or reused) material. In this paper, authors have considered that this industrial process is based on collection and 
separation, and have allocated this additional emergy as a purchased emergy. If one wants to allocate it to the product itself, by increasing its transformity in emergy table (as Table 1), then the additional emergy is considered in the non renewable part in the emergy assessment of a process. In this case of building construction, recycling and reusing would not have any impact on the ratios $E Y R_{B}$ and $E L R_{B}$ because the value $E_{B}^{0}$ is so significant that the additional emergy is negligible.

\section{Conclusion}

Emergy can be used successfully to evaluate systems with a fraction of its input materials derived from recycle sources, by effectively following the pathway of the material during the entire process (avoiding double counting). In this paper the methodology proposed by Amponsah et al. (2011) is applied and exemplified in the emergy evaluation of a low energy building in France. The evaluation results reveal significant impacts on the emergy yield ratio $\left(E Y R_{B}\right)$ and the emergy loading ratio $\left(E L R_{B}\right)$ of the building having a fraction of its input materials from recycled sources. The proposed methodology is important to provide the link between the emergy evaluation method and the hidden information in recycling materials severally. This is very useful for evaluating and improving systems which often have recycled inputs, to compare the usefulness of using raw material inputs or recycled inputs. Moreover, it enables an investigator to select optimum levels of recycling (amount to recycle and number of times of recycle) to achieve greater results towards sustainability. From the case study, every process in which a fraction of inputs can be traced to recycle sources, can be evaluated simply by applying the factor $\psi$. In this way the difficulty of recalculations is somehow reduced, since the factor could easily be selected depending on the time of recycling $\left(1^{\text {st }}, 2^{\text {nd }}, 3^{\text {rd }}\right.$ etc recycling). The results of $E Y R_{B}$ and $E L R_{B}$ substantiate the need for the continuous development of emergy as a useful analytical tool, due to its ability to account for the contribution of ecosystems to economic activity. Furthermore, emergy provides useful 
1 indicators for evaluating the ecological feasibility as well as sustainability of construction processes and buildings. The improved indicators proposed in this work provide a conceptually sound basis to quantify the impacts of recycling or reuse of materials in a typical low energy building. The calculated indicators were shown to be consistent with the notion that investing in waste management must be expected to lead to less environmental stress largely dependent on the input materials either from renewable, non renewable or purchased sources. A good balance of these would enhance sustainability.

In future works, it could be interesting to consider the emergy assessment for automotive since the part of recycling is rather important in this sector (up to 90\%). The consumer goods sector should also be studied through the emergy assessment as it is a non-negligible naturalresources consumption (e.g. packaging: metal cans, glass cans, paper, cardboard...).

\section{Acknowledgements}

This paper has been developed from the results obtained within the framework of the EQUER project "Low Energy Consumption Buildings" by graduate students of the Ecole des Mines de Nantes. The study also has had financial support from Ecole des Mines de Nantes and Carnot M.I.N.E.S of France. Authors would like to thank the two anonymous reviewers for their helpful comments.

\section{References}

1. Amponsah, N.Y., Le Corre, O., Lacarriere, B., 2011. Recycling flows in eMergy evaluation: a mathematical paradox? Ecological Modelling, vol, 222(17), pp. 3071-

2. Amponsah, N.Y. Contribution to the emergy theory: application to recycling, Ecole des Mines de Nantes, Ph.D. Thesis, 2011.

3. Anderson, R., Christensen, C., Horowitz, S., 2006. Program Design Analysis using 
to New Homes with Zero Peak Cooling Demand ACEEE, Summer Study Pacific Grove, California NREL/CP-550-39827.

4. Bastianoni, S., Campbell, D., Susani, L., Tiezzi E., 2005. The solar transformity of oil and petroleum natural gas, Ecological Modelling, vol. 186(2), pp. 212-220.

5. Brown, M.T., Arding, J.E., 1991. Transformity Working Paper, Center for Wetlands, University of Florida, FL.

6. Brown, M.T. Buranakarn, V., 2003. Emergy indices and ratios for sustainable material cycles and recycle options, Resources, Conservation and Recycling, vol. 38(1), pp. 122.

7. Buranakarn, V., Evaluation of recycling and reuse of building materials using the

8. Guinée, J.B., Huppes, G., Heijungs, R., 2001. Developing an LCA guide for decision support, Environmental Management and Health, vol. 12(3), pp. 301-311.

9. Huang, S., Hsu, W. 2003. Materials flow analysis and emergy evaluation of Taipei's urban construction, Landscape and Urban Planning, vol. 63(2), pp. 61-74.

10. Kralj, D., 2007. Environmental Waste Management in Constructions, Lecture Notes on Energy and Environment, WSEAS 07 (The World Scientific and Engineering Academy and Society), Archanchon, France.

11. Lagerberg, C., 1999. Emergy analysis of the resource use in greenhouse crop production and of the resource basis of the Swedish economy, Doctoral thesis presented to the Swedish University of Agricultural Sciences.

12. Meillaud, F., Gay, J.-B., Brown, M.T., 2005. Evaluation of a building using the emergy method, Solar Energy, vol. 79(2), pp. 204-212.

13. Odum, H.T., Odum, E.C., King, R., Richardson, R., 1987. Ecology and Economy: Emergy Analysis and Public Policy in Texas. Energy System in Texas and The United States, Policy Research Project Report Number 78, The Board of Regents, University of Texas, TX.

14. Odum, H.T., 1996. Environmental Accounting: Emergy and Environmental Decision Making, Chichester Wiley, New York. 
15. Odum, H.T., Brown, M.T., Williams, S.B., 2000. Handbook of Emergy Evaluation: A Compendium of Data for Emergy Computation Issued in a Series of Folios, Folio \#1Introduction and Global Budget, Center for Environmental Policy, University of Florida, Gainesville, FL.

16. Odum, H.T., 2002. Materials circulation, energy hierarchy, and building construction, In: Kibert, C.J., Sendzimir, J., Guy, G.B. (Eds.), Construction Ecology: Nature as the basis for Green Buildings, Spon Press, London, pp. 37-71.

17. Peuportier , B., Kohler, N., Boonstra, C., Blanc-Sommereux, I., Hamadou, H., Pagani, R., Gobin, C., Kreider J., 1996. European Methodology for the Evaluation of Environmental Impacts of Buildings. Project REGENER, Final Report to European Commission DG 12, 450pp.

18. Pulselli, R.M., Simoncini, E., Bastianoni, S., 2007. Emergy analysis of building manufacturing, maintenance and use: Em-building indices to evaluate housing sustainability, Energy and buildings, vol. 39(5), pp. 620-628.

19. Rees, W.E., Wackernagel, M., 1994. Ecological footprints and appropriated carrying capacity: Measuring the natural capital requirements of the human economy, in Jansson, A. et al., Investing in Natural Capital: The Ecological Economics Approach to Sustainability. Washington D.C.:Island Press. ISBN 1-55963-316-6.

20. Simoncini, E., 2006. Analisi emergetica di un edificio: effetti ambientali dimateriali e tecniche della bioarchitettura, Degree Thesis, available at: Dept. of Chemical and Biosystems Sciences, University of Siena, Italy.

21.Szargut, J., Morris, D.R., Steward, F.R., 1988. Exergy Analysis of Thermal, Chemical and Metallurgical Processes, Hemisphere Pubs., New York, 332pp.

22. U.E. 2007, (accessed on 16 March 2012)

\section{http://ec.europa.eu/energy/energy policy/doc/factsheets/mix/mix fr en.pdf}

23. Ulgiati, S., Raugei, M., Bargigli, S., 2004. Dotting the I's and Crossing the T's of emergy synthesis: material flows, information and memory aspects, and performance indicators. In: Proceedings from the Third Biennial Emergy Evaluation Research Conference, , Gainesville, FL. 
1 24. Wargocki P., Wyon, D.P., 2007. The effects of outdoor air supply rate and supply air filter condition in classrooms on the performance of schoolwork by children, HVAC\&R Research, vol.13(2), pp. 165-191.

\section{LIST OF FIGURES}

$6 \quad$ Figure 1: Emergy flows with additional emergy for recycling

7 Figure 2. Emergy inputs of main raw materials in constructing the building

8 Figure 3. Impact of $30 \%$ (constant rate) continuous bricks recycle (a) and reuse (b) on

$9 \quad \mathrm{EYR}_{\mathrm{B}}$ of the building

10 Figure 4. Impact of different recycling rates for continuous bricks recycle (a) and reuse (b)

11 on $\mathrm{EYR}_{\mathrm{B}}$ of the building

12 Figure 5. Impact of $30 \%$ (constant rate) continuous plastic recycle on $E Y R_{B}$ of the building

13 Figure 6. Impact of different recycling rates for continuous plastic recycle on $\mathrm{EYR}_{\mathrm{B}}$ of the 14 building

15 Figure 7. Impact of different recycle rates (a) and reuse rates (b) for continuous bricks 16 recycle on $\mathrm{ELR}_{\mathrm{B}}$ of the building

\section{LIST OF TABLES}

20 Table 1. Emergy evaluation Table

21 Table 2. Emergy results for bricks recycling for different recycling times.

22 Table 3. Difference in emergy involving a part of material recycle and initial emergy of 23 building for reuse of bricks (e.g. in concrete mix) 


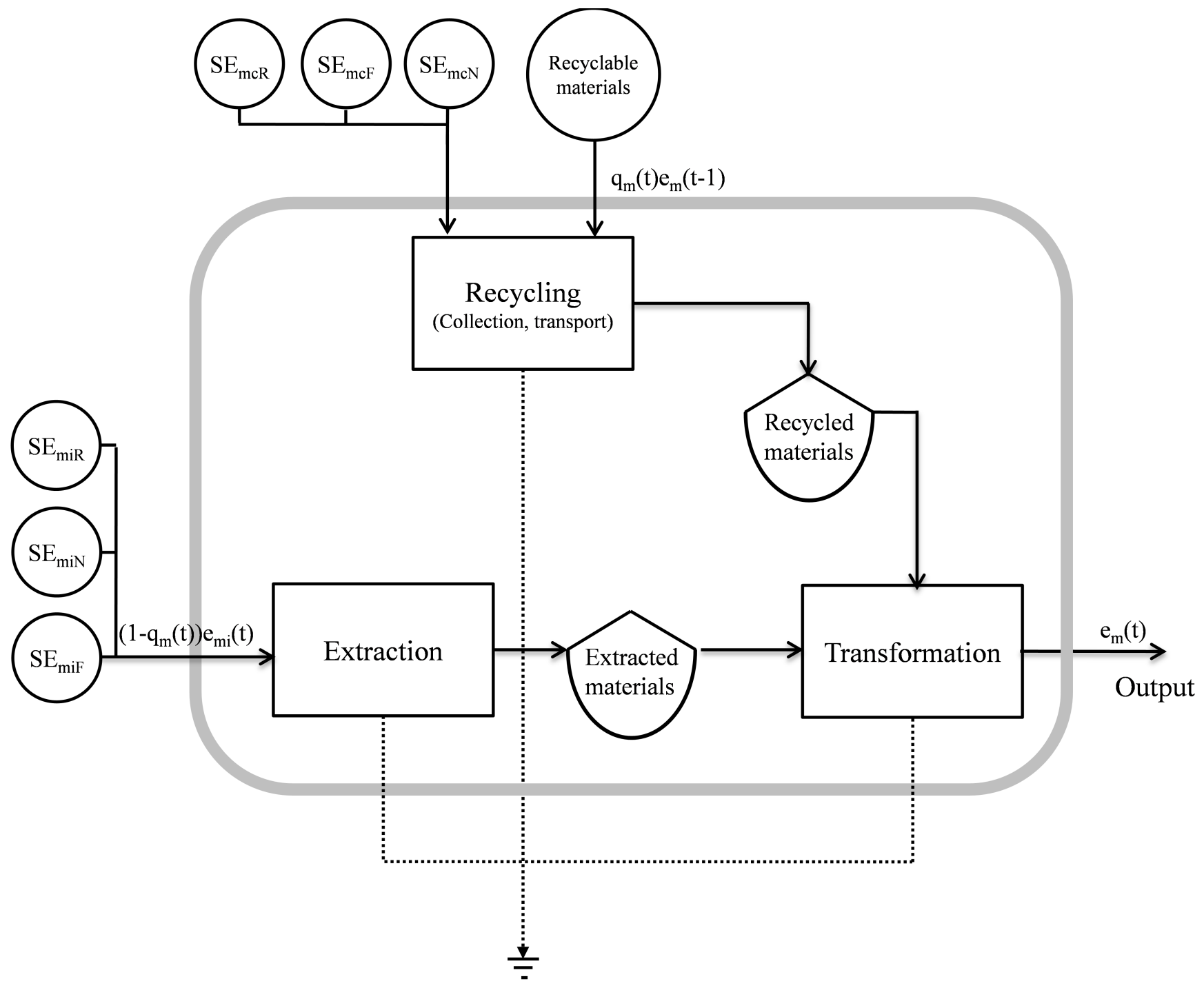


Figure 2

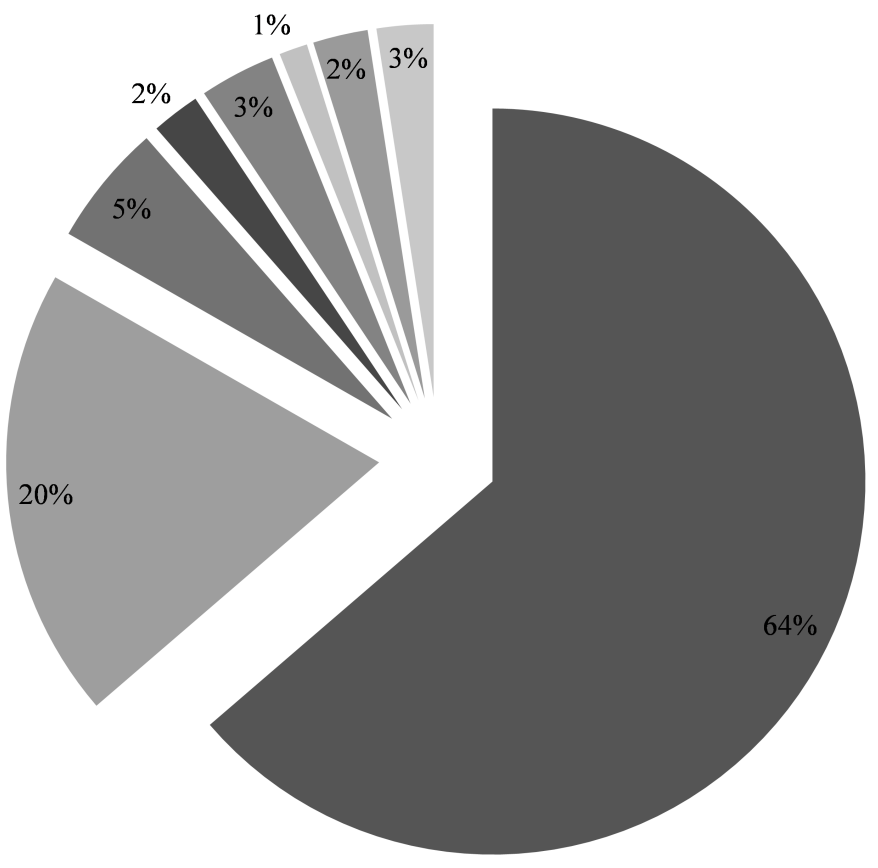

- Concrete

Bricks

- Mortar

- Wood

- Plaster

Tiles

PVC

Aluminium 


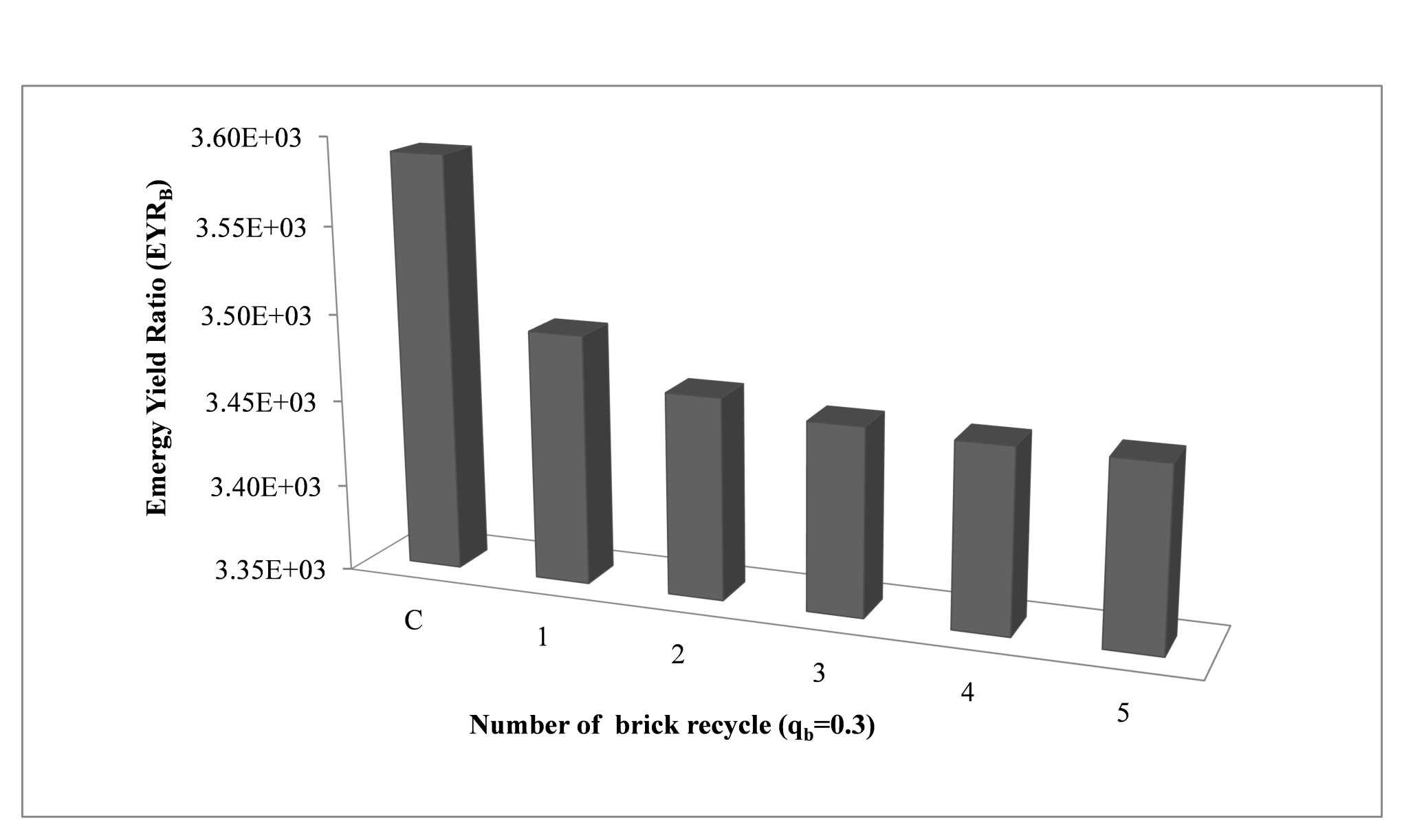

Figure 3a

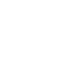

Figure $3 a$

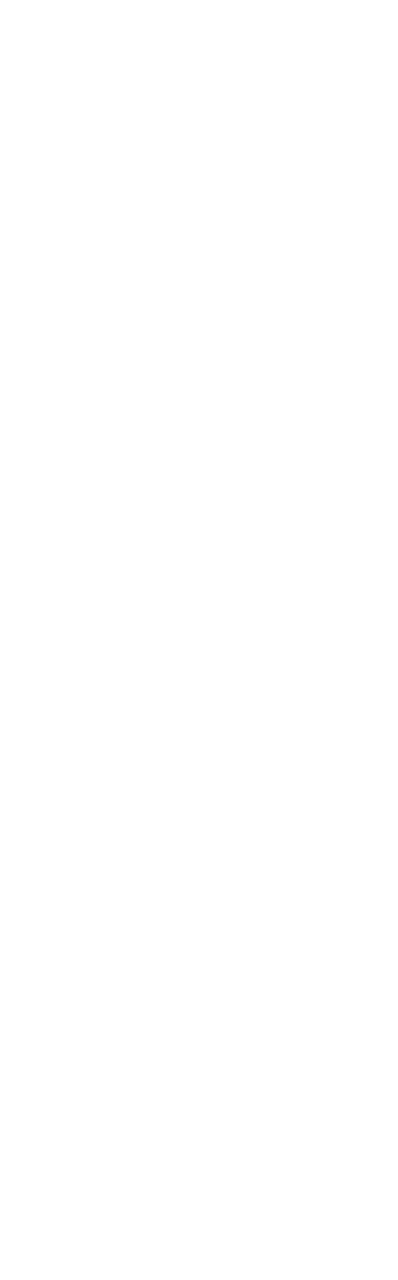




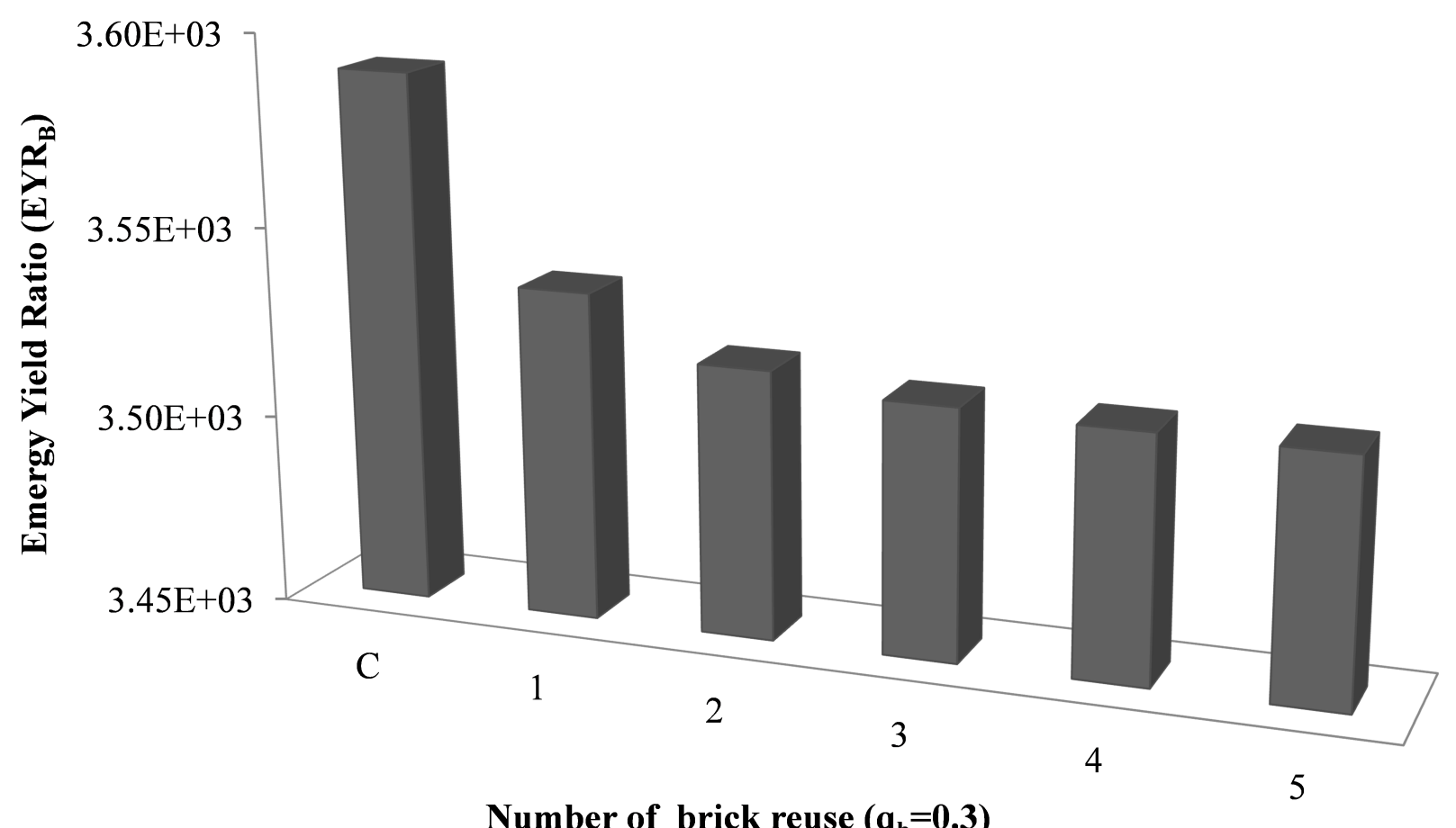

Number of brick reuse $\left(q_{b}=0.3\right)$ 


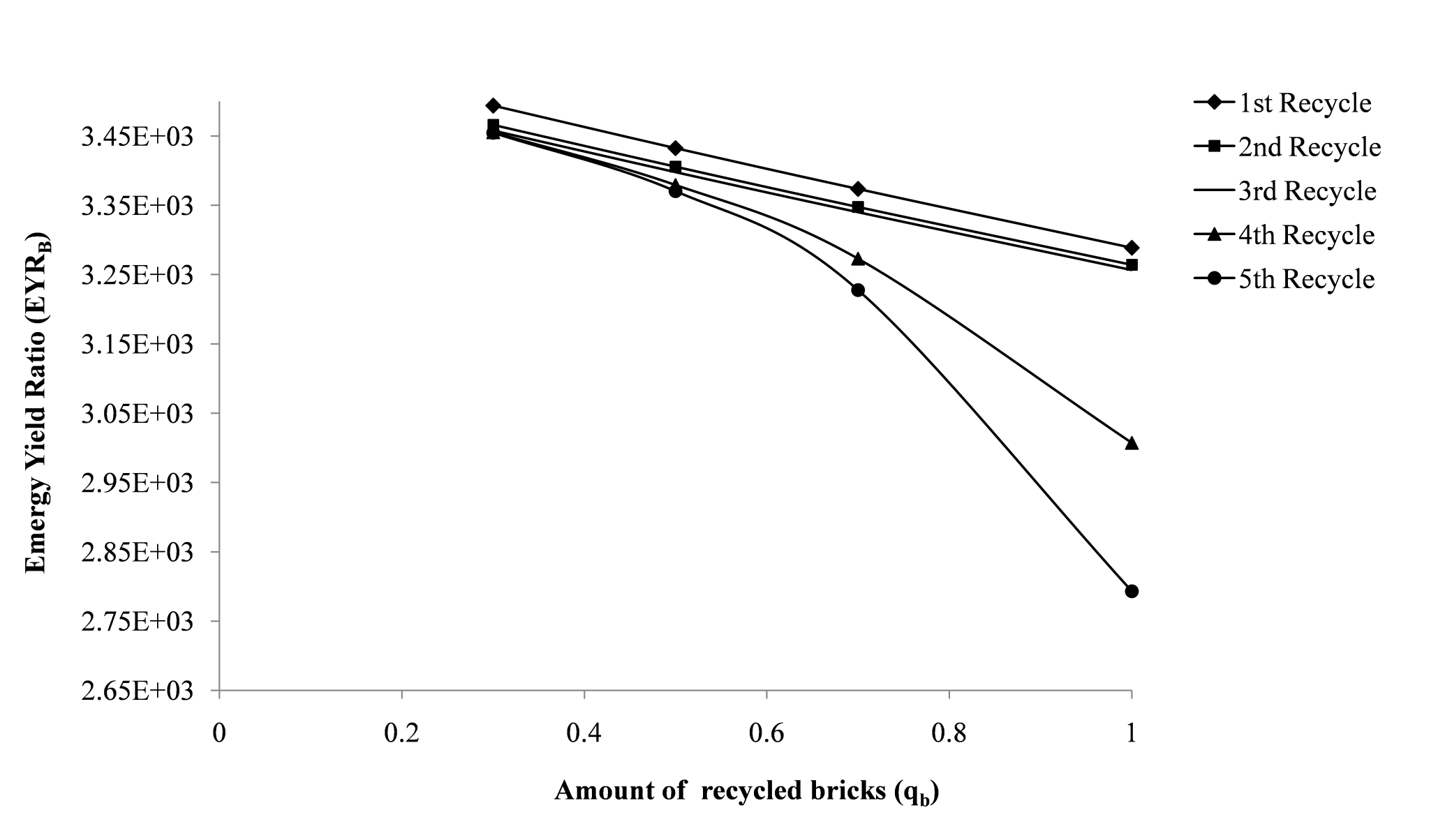

Figure $4 a$

\section{-}

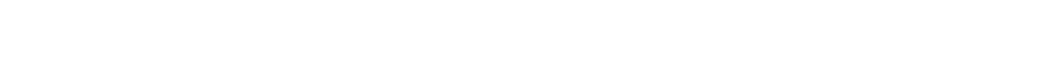

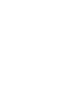

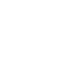

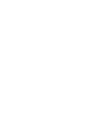

\section{Ament of recycled bricks (q)}


Figure $4 b$

Figure 4b

(n)

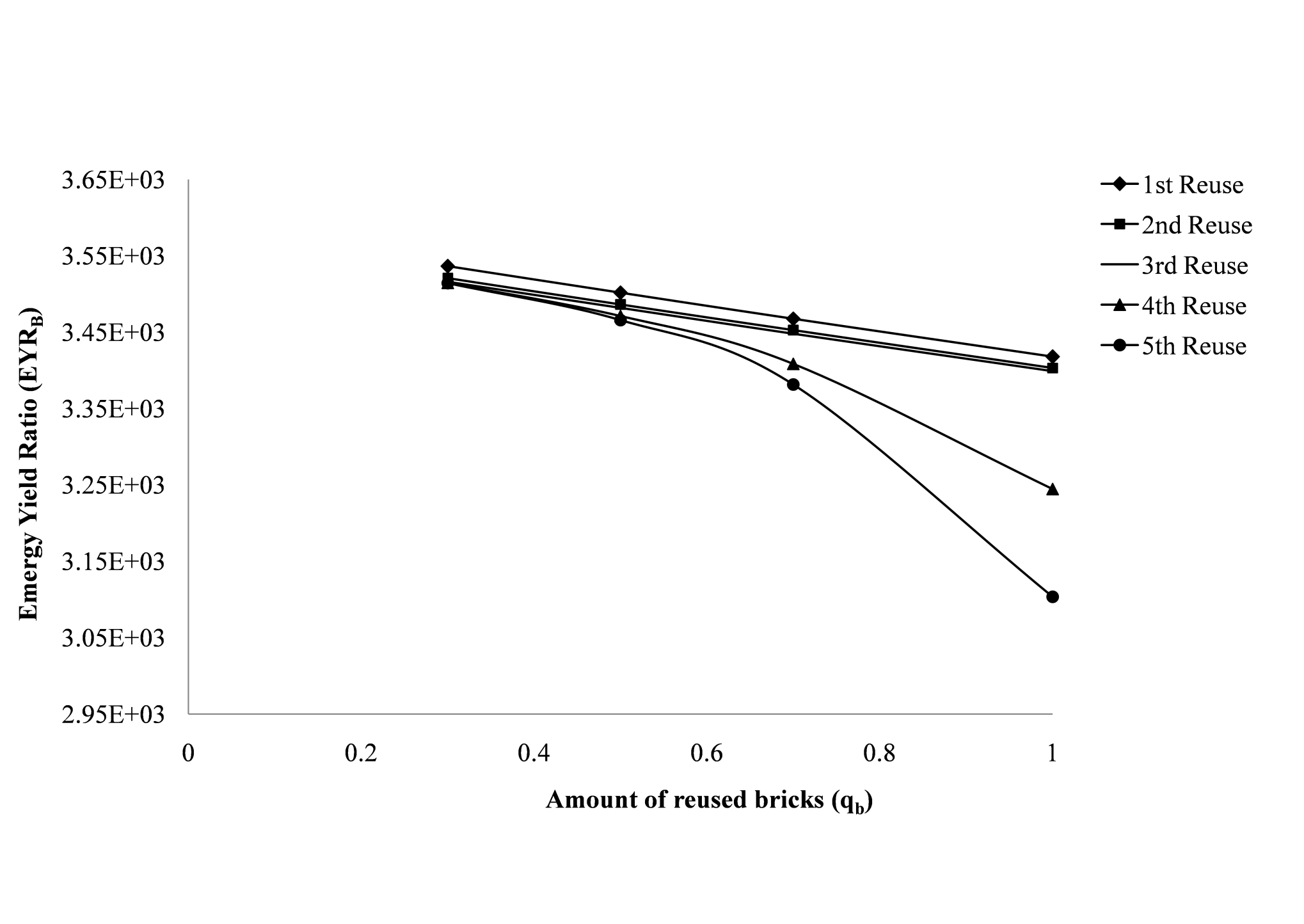

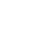

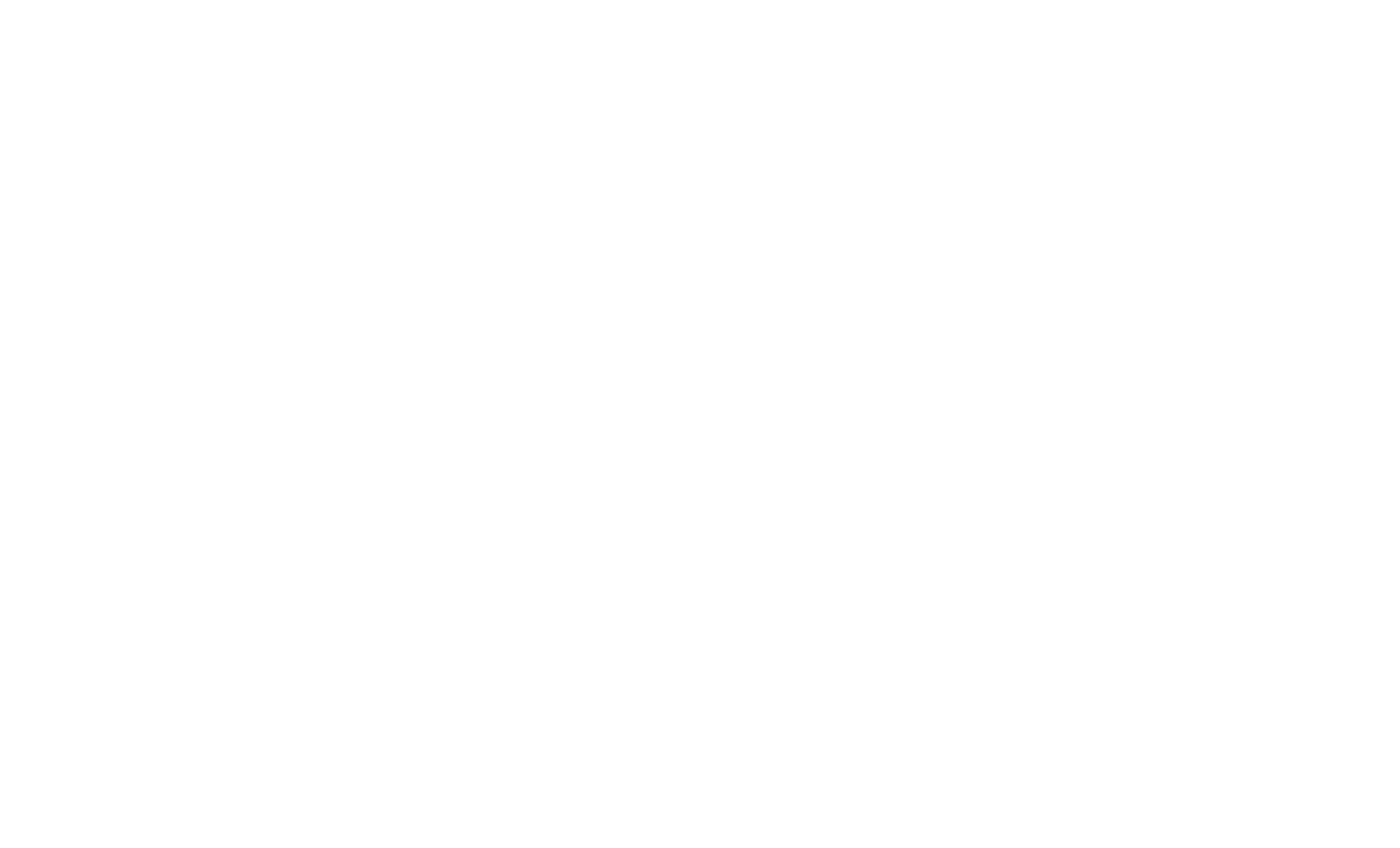

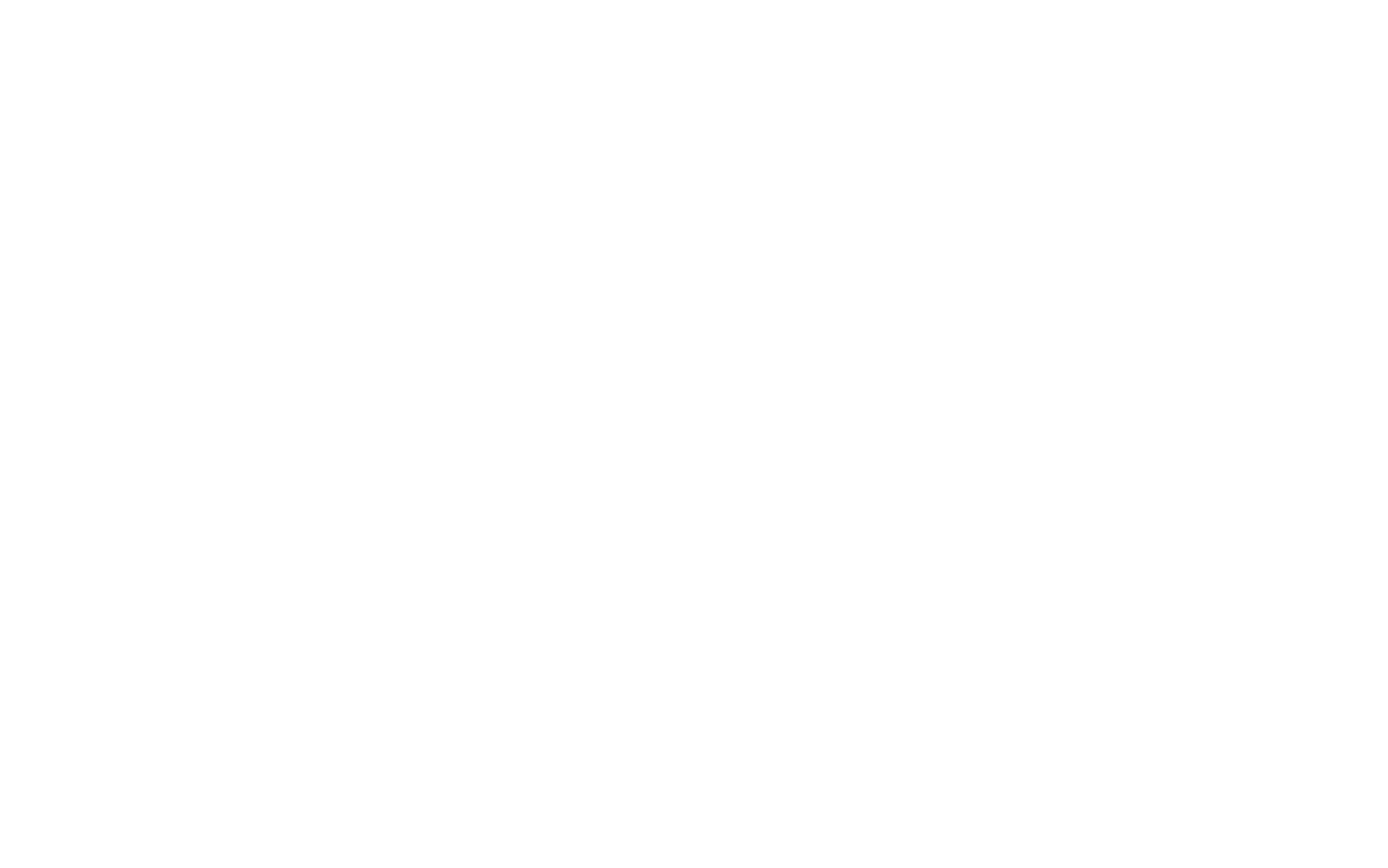

(1)

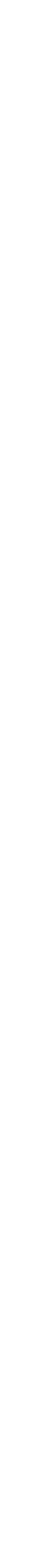




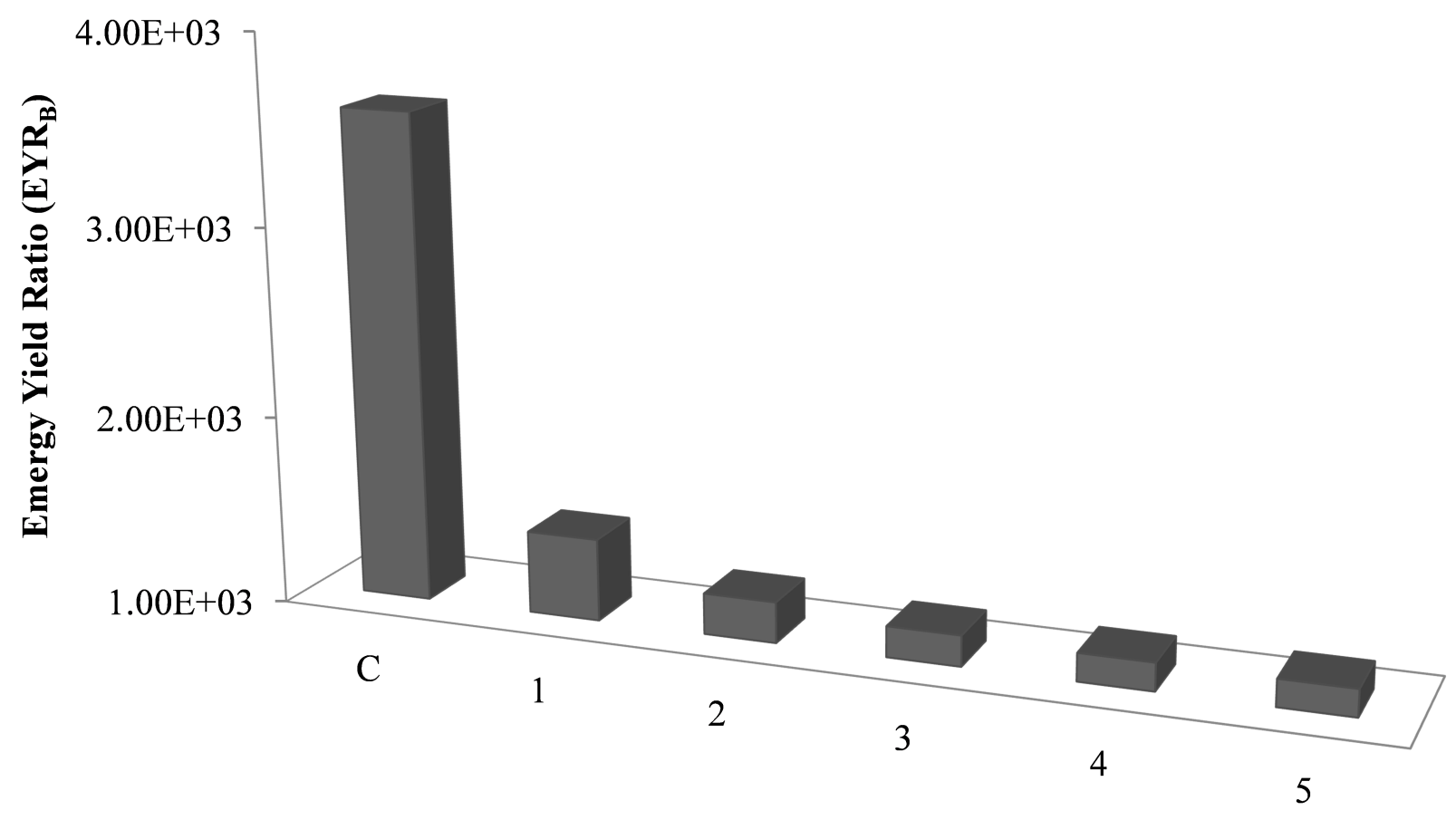

Number of recycled plastic $\left(q_{p}=0.3\right)$ 


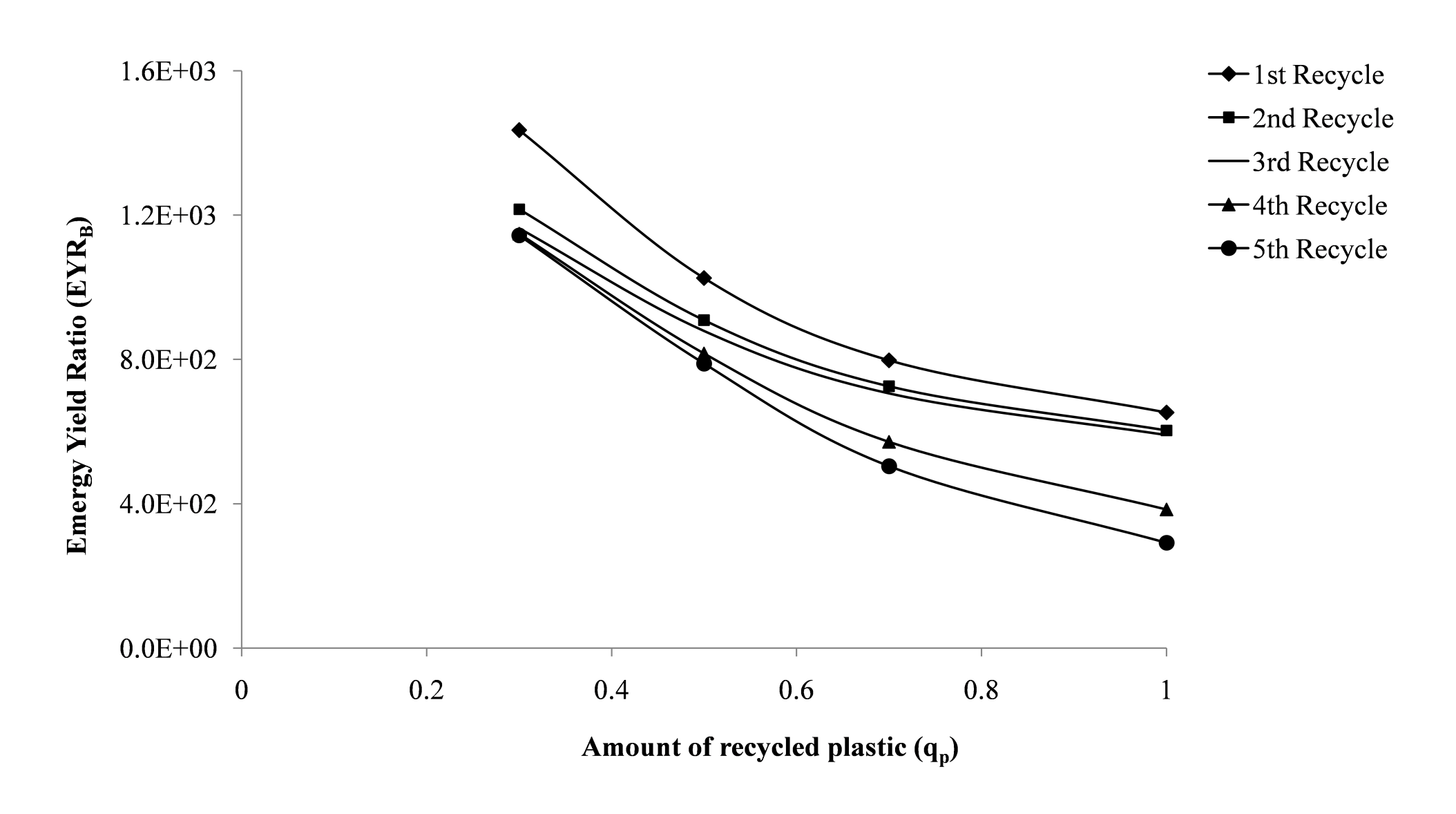

Figure 6

\section{Figure 6}

.

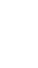

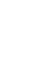

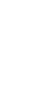

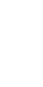

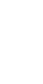
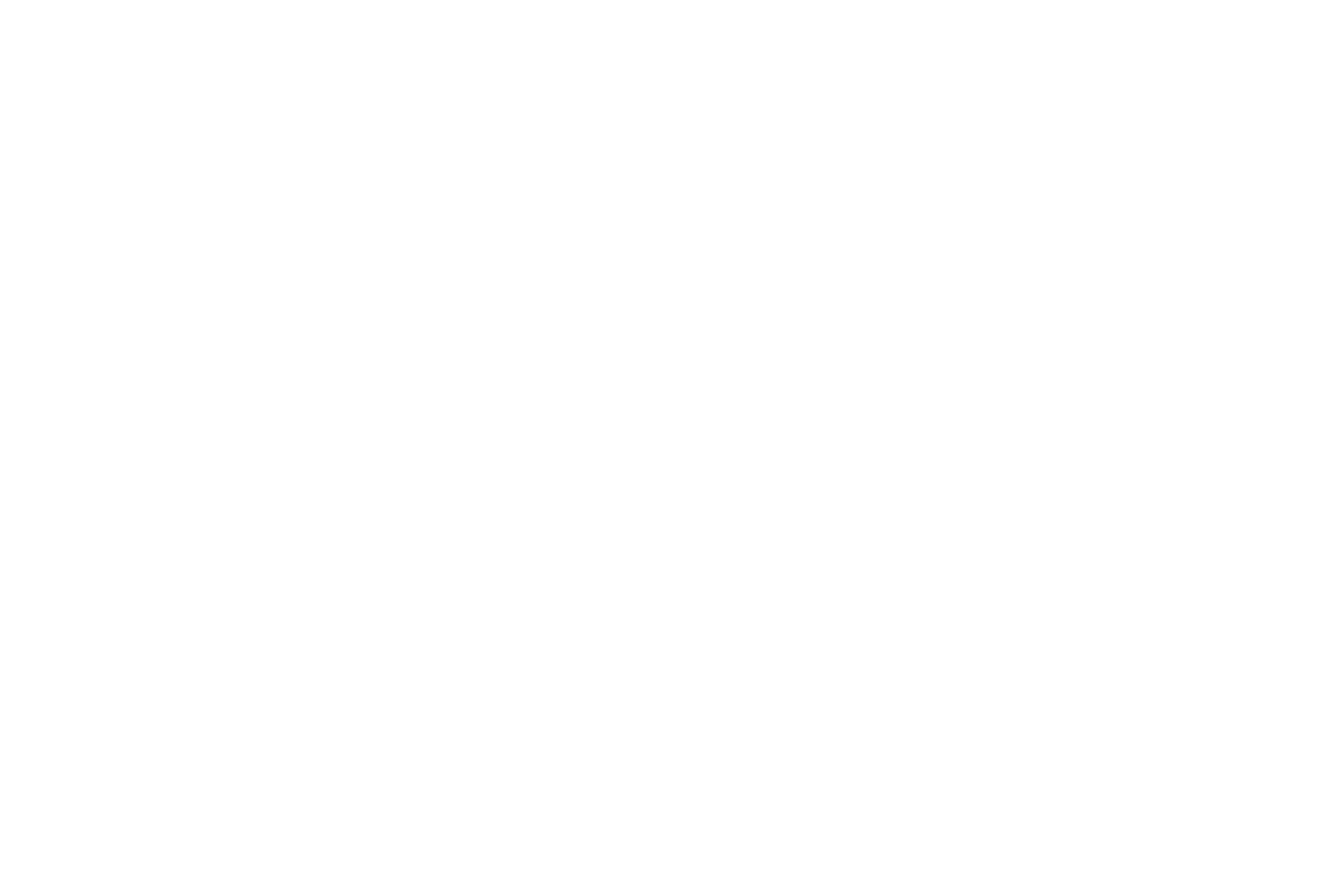

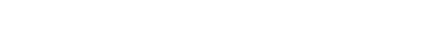
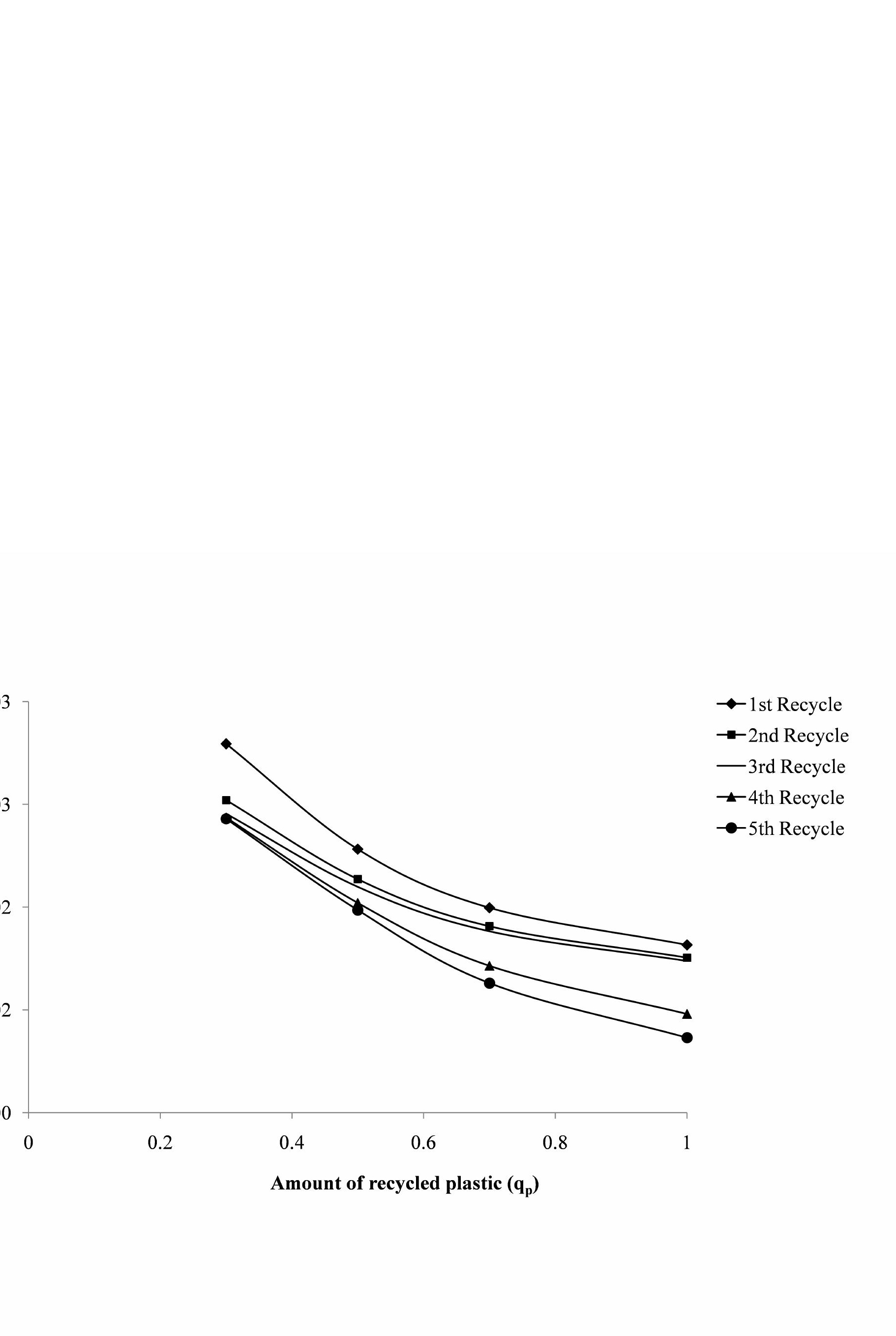


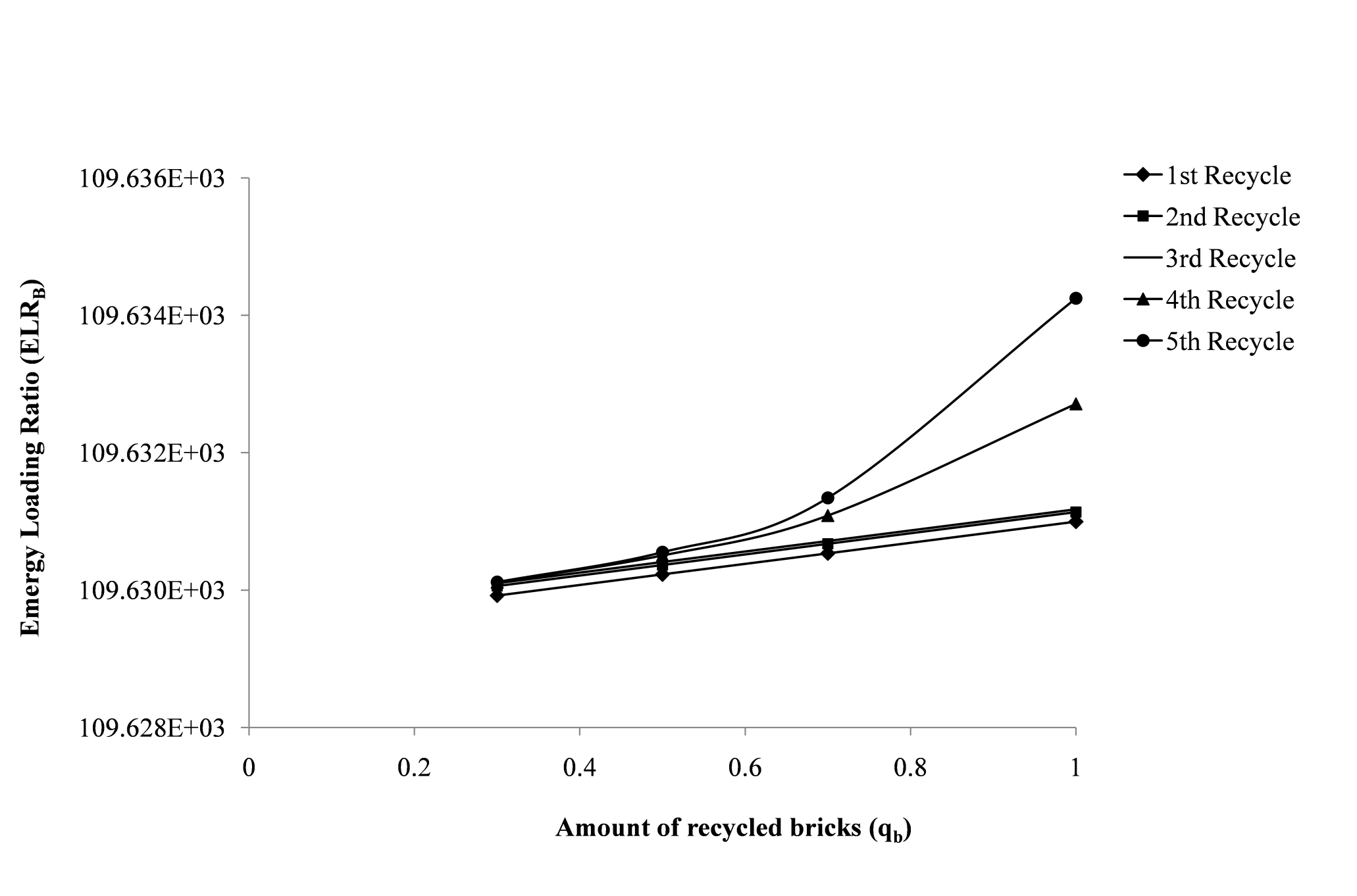

Figure 7a

.

要

.

a

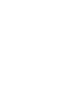
-

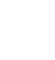
.

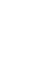

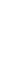

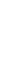

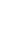
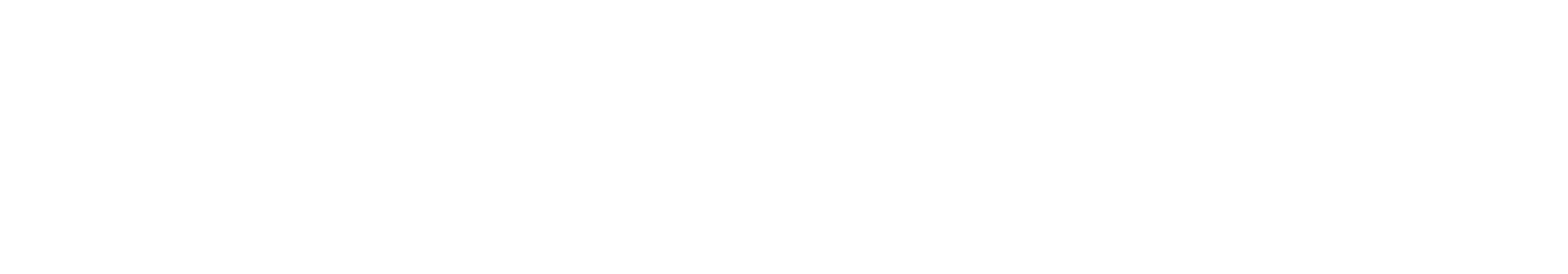


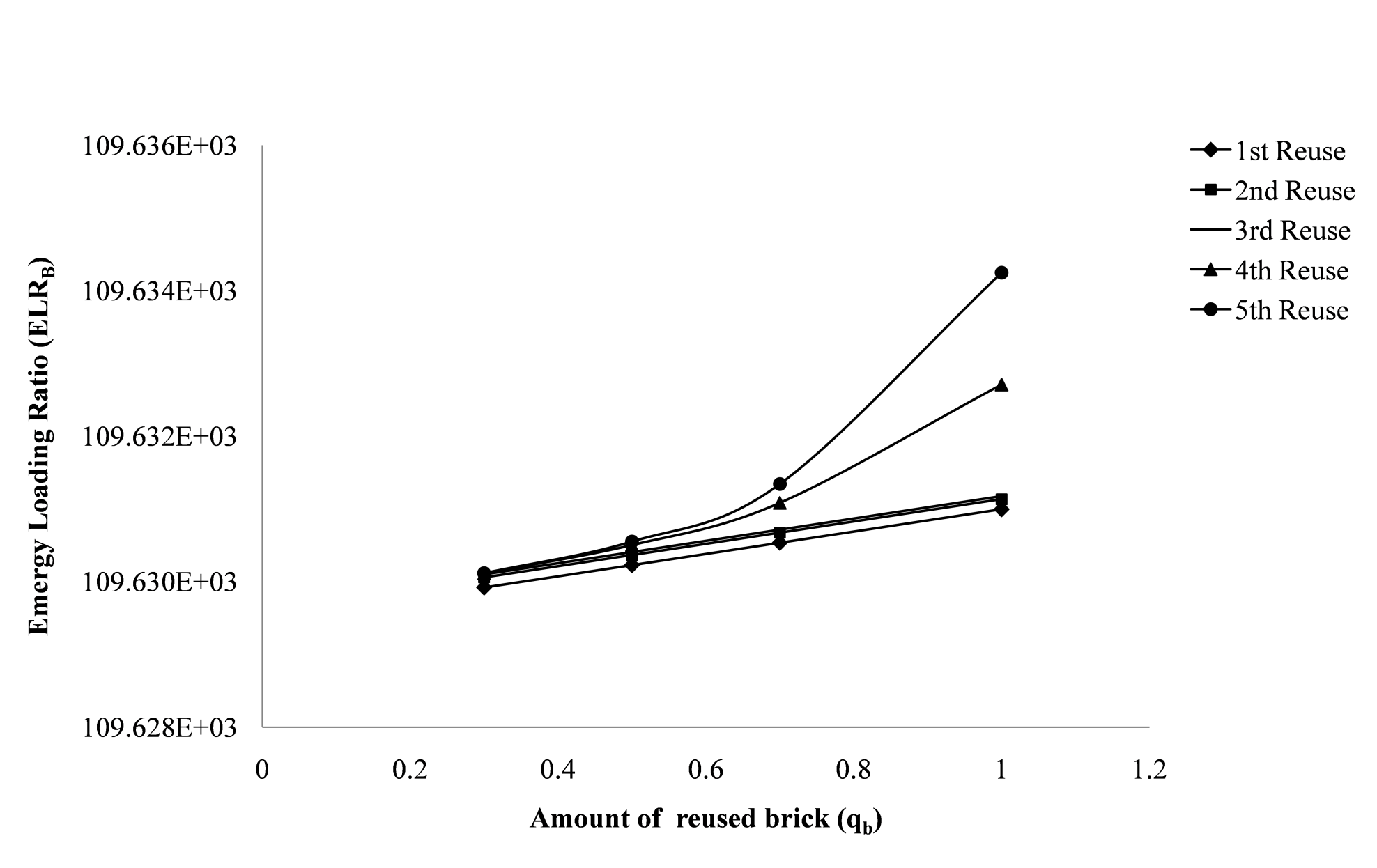

Figure $7 b$

Fure $7 \mathrm{~b}$

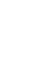

.

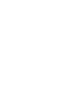
.

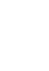

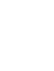

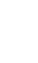

.

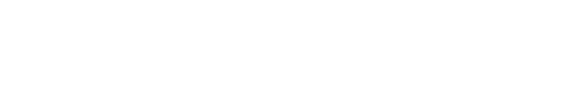

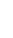

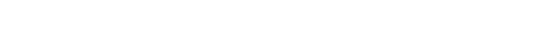

Amount of reused brick (q) 


\begin{tabular}{|c|c|c|c|c|c|c|c|c|}
\hline $\begin{array}{c}1 \\
\text { Note }\end{array}$ & $\begin{array}{c}2 \\
\text { Item }\end{array}$ & Density $\left(\mathrm{kg} / \mathrm{m}^{3}\right)$ & Volume $\left(\mathrm{m}^{3}\right)$ & $\begin{array}{c}3 \\
\text { Raw data }\end{array}$ & Unit & $\begin{array}{c}4 \\
\text { Transformity } \\
\text { (seJ/unit) }\end{array}$ & $\begin{array}{c}5 \\
\text { Ref. }\end{array}$ & $\begin{array}{c}6 \\
\text { Emergy (seJ) }\end{array}$ \\
\hline & Renewable Inputs & & & & & & & \\
\hline 1 & Sun & & & $6.19 \mathrm{E}+11$ & $J$ & $1.00 \mathrm{E}+00$ & a & $6.19 \mathrm{E}+11$ \\
\hline \multirow[t]{2}{*}{2} & water & 1000 & 614.52 & $6.15 \mathrm{E}+05$ & $\mathrm{~kg}$ & $4.80 \mathrm{E}+04$ & a & $2.95 \mathrm{E}+10$ \\
\hline & $\begin{array}{l}\text { Non Renewable Inpu } \\
\text { Basement (floor) }\end{array}$ & & & & & & & \\
\hline 3 & concrete & 1500 & 5.1 & 7718 & $\mathrm{~kg}$ & $1.81 \mathrm{E}+12$ & b & $1.40 \mathrm{E}+16$ \\
\hline 4 & Soft limestone & 1500 & 1.0 & 1544 & $\mathrm{~kg}$ & $1.68 \mathrm{E}+09$ & $f$ & $2.59 \mathrm{E}+12$ \\
\hline \multirow[t]{2}{*}{5} & Heavy concrete & 2300 & 0.5 & 1183 & $\mathrm{~kg}$ & $1.81 \mathrm{E}+12$ & b & $2.14 \mathrm{E}+15$ \\
\hline & Ground floor (floor) & & & & & & & \\
\hline 6 & concrete & 1300 & 0.8 & 1071 & $\mathrm{~kg}$ & $1.81 \mathrm{E}+12$ & b & $1.94 \mathrm{E}+15$ \\
\hline 7 & heavy concrete & 2300 & 0.2 & 474 & $\mathrm{~kg}$ & $1.81 \mathrm{E}+12$ & $\mathrm{~b}$ & $8.58 \mathrm{E}+14$ \\
\hline 8 & Polyurethane effisol & 35 & 0.3 & 11 & $\mathrm{~kg}$ & $8.85 \mathrm{E}+12$ & $c$ & $9.57 \mathrm{E}+13$ \\
\hline 9 & Mortar & 2000 & 0.3 & 618 & $\mathrm{~kg}$ & $3.31 \mathrm{E}+12$ & $c$ & $2.05 \mathrm{E}+15$ \\
\hline \multirow[t]{2}{*}{10} & Tiles & 2300 & 0.1 & 118 & $\mathrm{~kg}$ & $3.68 \mathrm{E}+12$ & c & $4.36 \mathrm{E}+14$ \\
\hline & Underground Wall & & & & & & & \\
\hline 11 & Concrete & 1500 & 5.2 & 7803 & $\mathrm{~kg}$ & $1.81 \mathrm{E}+12$ & b & $1.41 \mathrm{E}+16$ \\
\hline \multirow[t]{2}{*}{12} & Heavy concrete & 2300 & 1.0 & 2393 & $\mathrm{~kg}$ & $1.81 \mathrm{E}+12$ & b & $4.33 \mathrm{E}+15$ \\
\hline & Wall (on the west) & & & & & & & \\
\hline 13 & Light wood & 500 & 0.2 & 110 & $\mathrm{~kg}$ & $2.40 \mathrm{E}+12$ & $f$ & $2.64 \mathrm{E}+14$ \\
\hline 14 & Wooden fibre & 40 & 0.6 & 23 & $\mathrm{~kg}$ & $2.40 \mathrm{E}+12$ & $f$ & $5.64 \mathrm{E}+13$ \\
\hline 15 & Bricks & 741 & 2.8 & 2040 & $\mathrm{~kg}$ & $3.68 \mathrm{E}+12$ & $c$ & $7.51 \mathrm{E}+15$ \\
\hline 16 & Plaster & 1400 & 0.1 & 206 & $\mathrm{~kg}$ & $3.29 \mathrm{E}+12$ & $d$ & $6.76 \mathrm{E}+14$ \\
\hline 17 & Wooden panel & 120 & 0.02 & 2 & $\mathrm{~kg}$ & $2.40 \mathrm{E}+12$ & $f$ & $5.74 \mathrm{E}+12$ \\
\hline \multirow[t]{2}{*}{18} & plaster & 1200 & 0.02 & 24 & $\mathrm{~kg}$ & $3.29 \mathrm{E}+12$ & $d$ & $7.87 \mathrm{E}+13$ \\
\hline & Wall coating & & & & & & & \\
\hline 19 & Lime plaster & 1400 & 0.1 & 73 & $\mathrm{~kg}$ & $3.29 \mathrm{E}+12$ & $d$ & $2.41 \mathrm{E}+14$ \\
\hline 20 & Bricks & 741 & 1.0 & 727 & $\mathrm{~kg}$ & $3.68 \mathrm{E}+12$ & $\mathrm{c}$ & $2.67 \mathrm{E}+15$ \\
\hline \multirow[t]{2}{*}{21} & Plaster & 1400 & 0.1 & 73 & $\mathrm{~kg}$ & $3.29 \mathrm{E}+12$ & $d$ & $2.41 \mathrm{E}+14$ \\
\hline & Plastering & & & & & & & \\
\hline 22 & Plaster & 1400 & 0.01 & 14 & $\mathrm{~kg}$ & $3.29 \mathrm{E}+12$ & $d$ & $4.68 \mathrm{E}+13$ \\
\hline 23 & Concrete blocks & 1300 & 0.10 & 132 & $\mathrm{~kg}$ & $1.81 \mathrm{E}+12$ & $\mathrm{~b}$ & $2.39 \mathrm{E}+14$ \\
\hline \multirow[t]{2}{*}{24} & Lime plaster & 1400 & 0.01 & 14 & $\mathrm{~kg}$ & $3.29 \mathrm{E}+12$ & $d$ & $4.68 \mathrm{E}+13$ \\
\hline & Wall (East) & & & & & & & \\
\hline 25 & Porothermn bricks 30 & 762 & 0.3 & 196 & $\mathrm{~kg}$ & $3.68 \mathrm{E}+12$ & $c$ & $7.21 \mathrm{E}+14$ \\
\hline 26 & Bricks $10.7 \mathrm{~cm}$ & 1700 & 0.1 & 153 & $\mathrm{~kg}$ & $3.68 \mathrm{E}+12$ & $\mathrm{c}$ & $5.63 \mathrm{E}+14$ \\
\hline \multirow[t]{2}{*}{27} & Bricks $10.5 \mathrm{~cm}$ & 1700 & 0.1 & 153 & $\mathrm{~kg}$ & $3.68 \mathrm{E}+12$ & c & $5.63 \mathrm{E}+14$ \\
\hline & Wall (North) & & & & & & & \\
\hline 28 & Concrete & 1500 & 1.8 & 2694 & $\mathrm{~kg}$ & $1.81 \mathrm{E}+12$ & $\mathrm{~b}$ & $4.88 \mathrm{E}+15$ \\
\hline 29 & Bricks & 741 & 0.7 & 499 & $\mathrm{~kg}$ & $3.68 \mathrm{E}+12$ & c & $1.84 \mathrm{E}+15$ \\
\hline 30 & Wooden fibre & 40 & 0.1 & 3 & $\mathrm{~kg}$ & $2.40 \mathrm{E}+12$ & $f$ & $6.90 \mathrm{E}+12$ \\
\hline \multirow[t]{2}{*}{31} & Light wood & 500 & 0.1 & 27 & $\mathrm{~kg}$ & $2.40 \mathrm{E}+12$ & $f$ & $6.47 \mathrm{E}+13$ \\
\hline & Intermediate Floor & & & & & & & \\
\hline 32 & Plaster & 1500 & 0.1 & 154 & $\mathrm{~kg}$ & $3.29 \mathrm{E}+12$ & $d$ & $5.07 \mathrm{E}+14$ \\
\hline 33 & Concrete & 1300 & 0.6 & 802 & $\mathrm{~kg}$ & $1.81 \mathrm{E}+12$ & b & $1.45 \mathrm{E}+15$ \\
\hline 34 & Heavy concrete & 2300 & 0.2 & 473 & $\mathrm{~kg}$ & $1.81 \mathrm{E}+12$ & b & $8.56 \mathrm{E}+14$ \\
\hline 35 & Polystyrene extrude & 35 & 0.3 & 11 & $\mathrm{~kg}$ & $8.85 \mathrm{E}+12$ & c & $9.55 \mathrm{E}+13$ \\
\hline 36 & Mortar & 2000 & 0.3 & 514 & $\mathrm{~kg}$ & $3.31 \mathrm{E}+12$ & $c$ & $1.70 \mathrm{E}+15$ \\
\hline \multirow[t]{2}{*}{37} & Tiles & 2300 & 0.1 & 118 & $\mathrm{~kg}$ & $3.68 \mathrm{E}+12$ & c & $4.35 \mathrm{E}+14$ \\
\hline & Room Partitioning & & & & & & & \\
\hline 38 & Plaster & 1200 & 0.1 & 74 & $\mathrm{~kg}$ & $3.29 \mathrm{E}+12$ & $d$ & $2.44 \mathrm{E}+14$ \\
\hline 39 & Wooden fibre & 40 & 0.5 & 20 & $\mathrm{~kg}$ & $2.40 \mathrm{E}+12$ & b & $4.75 E+13$ \\
\hline 40 & Plaster+cellulose & 1200 & 0.1 & 74 & $\mathrm{~kg}$ & $3.29 \mathrm{E}+12$ & d & $2.44 \mathrm{E}+14$ \\
\hline \multirow[t]{2}{*}{41} & Concrete & 600 & 0.1 & 73 & $\mathrm{~kg}$ & $1.81 \mathrm{E}+12$ & $\mathrm{~b}$ & $1.33 \mathrm{E}+14$ \\
\hline & Roof rafters & & & & & & & \\
\hline 42 & Terracotta & 1900 & 0.1 & 153 & $\mathrm{~kg}$ & $1.68 \mathrm{E}+09$ & $b$ & $2.57 \mathrm{E}+11$ \\
\hline 43 & Air space & 1 & 0.0 & 0.04 & $\mathrm{~kg}$ & $6.97 \mathrm{E}+12$ & a & $2.80 \mathrm{E}+11$ \\
\hline 44 & Wooden fibre & 40 & 0.5 & 19 & $\mathrm{~kg}$ & $2.40 \mathrm{E}+12$ & $\mathrm{~b}$ & $4.63 \mathrm{E}+13$ \\
\hline 45 & Wooden board & 800 & 0.1 & 43 & $\mathrm{~kg}$ & $2.40 \mathrm{E}+12$ & b & $1.03 \mathrm{E}+14$ \\
\hline
\end{tabular}




\begin{tabular}{|c|c|c|c|c|c|c|c|c|}
\hline $\begin{array}{c}1 \\
\text { Note }\end{array}$ & $\begin{array}{l} \\
\text { Item }\end{array}$ & Density $\left(\mathrm{kg} / \mathrm{m}^{3}\right)$ & Volume $\left(\mathrm{m}^{3}\right)$ & $\begin{array}{c}3 \\
\text { Raw data }\end{array}$ & Unit & $\begin{array}{c}4 \\
\text { Transformity } \\
\text { (seJ/unit) }\end{array}$ & $\begin{array}{c}5 \\
\text { Ref. }\end{array}$ & $\begin{array}{c}6 \\
\text { Emergy (seJ) }\end{array}$ \\
\hline & Upstairs Roofing & & & & & & & \\
\hline 46 & Terracotta & 1900 & 0.1 & 165 & $\mathrm{~kg}$ & $1.68 \mathrm{E}+09$ & b & $2.78 \mathrm{E}+11$ \\
\hline 47 & Air space $>1.3 \mathrm{~cm}$ & 1 & 0.0 & 0.04 & $\mathrm{~kg}$ & $6.97 \mathrm{E}+12$ & a & $3.03 \mathrm{E}+11$ \\
\hline 48 & Wooden fibre & 40 & 0.5 & 21 & $\mathrm{~kg}$ & $2.40 \mathrm{E}+12$ & b & $5.01 \mathrm{E}+13$ \\
\hline 49 & Light wood & 800 & 0.1 & 46 & $\mathrm{~kg}$ & $2.40 \mathrm{E}+12$ & $\mathrm{~b}$ & $1.11 \mathrm{E}+14$ \\
\hline 50 & Interior wooden door & 750 & 0.06 & 48 & $\mathrm{~kg}$ & $2.40 \mathrm{E}+12$ & b & $1.15 \mathrm{E}+14$ \\
\hline 60 & $\begin{array}{l}\text { Double glass window for } \\
\text { external door } 4,16,4 \text { argon }\end{array}$ & 2700 & 0.03 & 82 & $\mathrm{~kg}$ & $2.13 \mathrm{E}+13$ & $c$ & $1.74 \mathrm{E}+15$ \\
\hline 61 & Glass Window & 2700 & 0.02 & 44 & $\mathrm{~kg}$ & $1.41 \mathrm{E}+12$ & e & $6.18 \mathrm{E}+13$ \\
\hline 62 & External wooden door & 750 & 0.06 & 41 & $\mathrm{~kg}$ & $2.40 \mathrm{E}+12$ & $b$ & $9.91 \mathrm{E}+13$ \\
\hline 63 & metallic gate & 7874 & 0.01 & 48 & $\mathrm{~kg}$ & $8.55 \mathrm{E}+08$ & a & 4.12E+10 \\
\hline 64 & Drainage system (PVC) & & & 171 & $\mathrm{~kg}$ & $9.86 \mathrm{E}+12$ & c & $1.69 \mathrm{E}+15$ \\
\hline \multirow[t]{2}{*}{65} & Staircase (wood) & & & 300 & $\mathrm{~kg}$ & $2.40 \mathrm{E}+12$ & $b$ & $7.20 \mathrm{E}+14$ \\
\hline & Purchased Inputs & & & & & & & \\
\hline \multirow[t]{2}{*}{66} & Fuel (Transports) & & & $1.74 \mathrm{E}+08$ & $J$ & $1.13 \mathrm{E}+05$ & $\mathrm{~h}$ & $1.96 \mathrm{E}+13$ \\
\hline & \multicolumn{8}{|c|}{ Energy consumed (Electricity use on site) } \\
\hline 67 & Nuclear $(78 \%)$ & & & $8.88 \mathrm{E}+05$ & $\mathrm{~J}$ & $2.00 E+05$ & g & $1.78 \mathrm{E}+11$ \\
\hline 68 & Hydro (14\%) & & & $1.59 \mathrm{E}+05$ & $\mathrm{~J}$ & $8.00 \mathrm{E}+04$ & a & $1.28 \mathrm{E}+10$ \\
\hline 69 & Natural gas (4\%) & & & $4.56 \mathrm{E}+04$ & $\mathrm{~J}$ & $4.80 \mathrm{E}+04$ & a & $2.19 \mathrm{E}+09$ \\
\hline \multirow[t]{2}{*}{70} & Coal $(4 \%)$ & & & $4.56 \mathrm{E}+04$ & $\mathrm{~J}$ & $4.00 \mathrm{E}+04$ & a & $1.82 \mathrm{E}+09$ \\
\hline & Total emergy for building $\mathrm{m}$ & cturing & & & & & & $7.11 \mathrm{E}+16$ \\
\hline
\end{tabular}

[a] Odum et al. (2000); [b] Simoncini (2006); [c] Brown and Buranakarn (2003); [d] Meillaud et al. (2005); [e] Odum et al. (1987); [f] Odum (1996); [g] Brown and Arding (1991); [h] Bastianoni et al. (2005)

Table 1. Emergy evaluation Table 
Table 2

$\psi \mathrm{Ec}$, seJ

\begin{tabular}{ll}
\hline Recycling & \\
1st & $5.4 \mathrm{E}+11$ \\
2nd & $7.1 \mathrm{E}+11$ \\
3rd & $7.6 \mathrm{E}+11$ \\
4th & $7.7 \mathrm{E}+11$ \\
5 th & $7.8 \mathrm{E}+11$ \\
\hline
\end{tabular}

Table 2. Results of bricks recycling for different number of recycling times 
Table 3

Difference with initial emergy seJ

\begin{tabular}{ll}
\hline Reuse & \\
1st & $2.99 \mathrm{E}+11$ \\
2nd & $3.89 \mathrm{E}+11$ \\
3rd & $4.15 \mathrm{E}+11$ \\
4th & $4.24 \mathrm{E}+11$ \\
5 th & $4.26 \mathrm{E}+11$ \\
\hline
\end{tabular}

Table 3. Results of new emergy of building for reuse of bricks (e.g. in concrete mix) 